\title{
Biometric Estimation of Carbon Storage in Hevea brasiliensis Planted in Different Densities
}

\author{
Rasyidah Mohamad Razar, Mohd Nasaruddin Mohd Aris \\ Production Development Division, Malaysian Rubber Board, Sungai Buloh, Malaysia \\ Email: rasyidah.mohamadra25@uga.edu
}

How to cite this paper: Razar, R.M. and Aris, M.N.M. (2018) Biometric Estimation of Carbon Storage in Hevea brasiliensis Planted in Different Densities. Open Access Library Journal, 5: e4836.

https://doi.org/10.4236/oalib.1104836

Received: August 14, 2018

Accepted: September 15, 2018

Published: September 18, 2018

Copyright $\odot 2018$ by authors and Open Access Library Inc.

This work is licensed under the Creative Commons Attribution International License (CC BY 4.0).

http://creativecommons.org/licenses/by/4.0/

\section{(c) () Open Access}

\begin{abstract}
Carbon pool can be found in all four spheres of earth and the flux of carbon from one pool to another would result in climate change. An increased awareness to offset release of carbon in the atmosphere is emphasized in the United Nations Framework Convention on Climate Change through Kyoto Protocol. The establishment of rubber forest for the purpose of reducing atmospheric carbon is one of the options to sequester carbon in addition to benefitting from timber harvests at the end of crop rotation. The study analysed carbon concentration and carbon content in all plant parts of eleven-years-old rubber clones; RRIM 2020 and RRIM 2025 planted in four planting densities; 500, 1000, 1500 and 2000 plants/ha. Carbon concentration was found the highest in leaf of RRIM 2020 at 500 plants/ha density $(53.3 \% \pm$ $0.2 \%)$. This could be explained by the presence of photosynthetic activity and the resulted high amount of lignin. Carbon content is found the highest in large branch of RRIM 2020 at 500 plants/ha density $(93.04 \pm 11.22 \mathrm{~kg}$ ), because of the high biomass weight of large branch and the abundant amount of lignocellulosic material. Trend analysis of total carbon sequestered in plant parts with planting density was found to be in negative pattern; quadratic and cubic regression for RRIM 2020 and RRIM 2025, respectively. However when total carbon content per hectare was calculated it was found that carbon content was the highest at 1500 plants/ha density $(140.355 \pm 9888 \mathrm{~kg}$, clone RRIM 2025). Even though high density planting gave higher carbon sequestration per hectare, planting at 500 plants/ha is still recommended as this gives more biomass weight to rubber plant parts and thus subsequently benefits the timber industry.
\end{abstract}

\section{Subject Areas}

Genetics, Plant Science 


\section{Keywords}

Biometric, Carbon sequestration, Rubber Forest Plantation, Density, Regression

\section{Introduction}

Carbon is the basic building block of all elements necessary for life. Carbon is able to easily bind with other atoms to form different chemical compounds and thus constitute major forms of earth structure. The earth consists of four spheres which pertain to the earth's major reservoirs of matter and energy. These are the lithosphere, the biosphere, the atmosphere and the hydrosphere. Each of the earth's spheres contain carbon; i.e. carbon is found in the atmosphere mostly as carbon dioxide; carbon is found in the lithosphere stored in carbonate rocks; it is also found in fossil fuels such as oil, coal and natural gas, carbon is found in the biosphere stored in plants and trees and finally carbon is found in the hydrosphere dissolved in ocean water and lakes. These entire sources of carbon are termed carbon pool [1].

The flux of carbon from one pool to another is the basis for the carbon cycle. As carbon moves between the spheres, it affects or is affected by climate change [1]. Extra carbon in the atmosphere is leading to global warming over and above natural levels. Carbon dioxide $\left(\mathrm{CO}_{2}\right)$ is the most common gaseous form of carbon. Together with methane $\left(\mathrm{CH}_{4}\right)$ they are principle greenhouse gases. Methane produces a large greenhouse effect per volume as compared to carbon dioxide, but it exists in much lower concentrations and is more short-lived than carbon dioxide, making carbon dioxide the more important greenhouse gas of the two [2]. The increasing atmospheric $\mathrm{CO}_{2}$ is caused by anthropogenic emissions of $\mathrm{CO}_{2}$, where three-quarters of emissions are due to fossil fuel burning. Fossil fuel burning plus a small contribution from cement production released on average $5.4 \pm 0.3 \mathrm{PgC} / \mathrm{yr}$ during 1980 to 1989 and $6.3 \pm 0.4 \mathrm{PgC} / \mathrm{yr}$ during 1990 to 1999 [3]. Carbon is also significantly emitted through the change in land use [3].

Greenhouse gasses act by warming the atmosphere by permitting the sunlight to reach the surface of the earth, but preventing some heat from escaping the earth's atmosphere. The nature of $\mathrm{CO}_{2}$ which absorbs and emits infrared radiation at $4.26 \mu \mathrm{m}$ and $14.99 \mu \mathrm{m}$ wavelengths renders the atmosphere warmer [4]. Carbon dioxide in a small quantity is indeed important for the survival of earth inhabitants, however if the level gets higher it could lead to unnecessary temperature rising and increase the frequency of extreme weather events. Possible effects of this include impacts on agriculture and food production, damage to natural ecosystem, rise of sea level due to melting of polar ice caps, food and freshwater supplies, and altered disease pattern [5].

Reduction of atmospheric carbon can be achieved through carbon sequestration. Carbon sequestration can be defined as the capture and secure storage of 
carbon that would otherwise be emitted to, or remain, in the atmosphere [6]. Natural carbon sequestration is a long term storage of carbon that take place in oceans, soils, vegetation (especially forests), and geologic formations. Technological strategies to reduce carbon emissions include developing energy efficient fuels and efforts to develop and implement non-carbon energy sources. The establishment of forest for the purpose of reducing atmospheric carbon is one of the options to sequester carbon. As forests grow, they store carbon in woody tissues and soil organic matter [7]. Many studies of Amazonian forests suggested that tropical forests could be large terrestrial sinks for carbon [8]-[13]. Tropical forests account for $40 \%$ of carbon stored globally in terrestrial biomass [14] and contribute as much as $36 \%$ of the net exchange between atmosphere and terrestrial vegetation [15]. A tropical climate country such as Malaysia could as well adopt the strategy of forest establishment, in particular rubber forest plantation with the main aim to sequester carbon while timber and latex harvestings as secondary functions.

In present study, carbon content is calculated in rubber tree by using the biometric technique. This technique refers to the observation of plot scale to the individual tree biomass in forested area that generally covered an area not exceeding 60 hectares [16]. For this study total carbon was measured in different plant parts of eleven-years-old rubber clone; RRIM 2020 and RRIM 2025, planted in four densities; 500, 1000, 1500 and 2000 plants/hectare. The objectives were to evaluate which planting densities could give rise to the highest total carbon (per tree and per hectarage area), to identify which plant parts sequester the most carbon, to observe any strong correlation between carbon in plant parts and carbon per tree and finally to derive regression equation between density and total carbon, and between total carbon per whole and carbon content in plant parts.

\section{Materials and Methods}

Eleven year old rubber clones planted at RRIMNIS Tok Dor in Terengganu, Malaysia which comprises of RRIM 2020 and RRIM 2025, planted in four densities; 500, 1000, 1500 and 2000 plants/hectare were uprooted with three replications for each density. Plant parts were separated and weighed to get total fresh weight. A small portion of sample was dried at $60^{\circ} \mathrm{C}$ convection oven for a week and dry weight was measured after that. Sample was then milled to $1 \mathrm{~mm}$ particle diameter size and three replicates per sample were submitted to the Quality and Technical Services Division of Malaysian Rubber Board for carbon concentration analysis. The amount of carbon was expressed in units of percent carbon by dry weight. The data were analysed using Proc Means, ANOVA, Duncan's multiple range test, and Pearson correlation coefficients of SAS software. Regression plot and equation, and Student t-test were calculated using SPSS.

\section{Results}

Summary of total fresh weight (TFW), total dry weight (TDW) and moisture 
content (MC) for each plant parts of RRIM 2020 and RRIM 2025 are given in Table 1(a) and Table 1(b). In 500 plants/ha planting density the highest TFW

Table 1. (a) Total fresh weight, total dry weight and moisture content of eleven-years-old rubber clones planted at 500 and 1000 plants/ha densities; (b) Total fresh weight, total dry weight and moisture content of eleven-years-old rubber clones planted at 1500 and 2000 plants/ha densities.

(a)

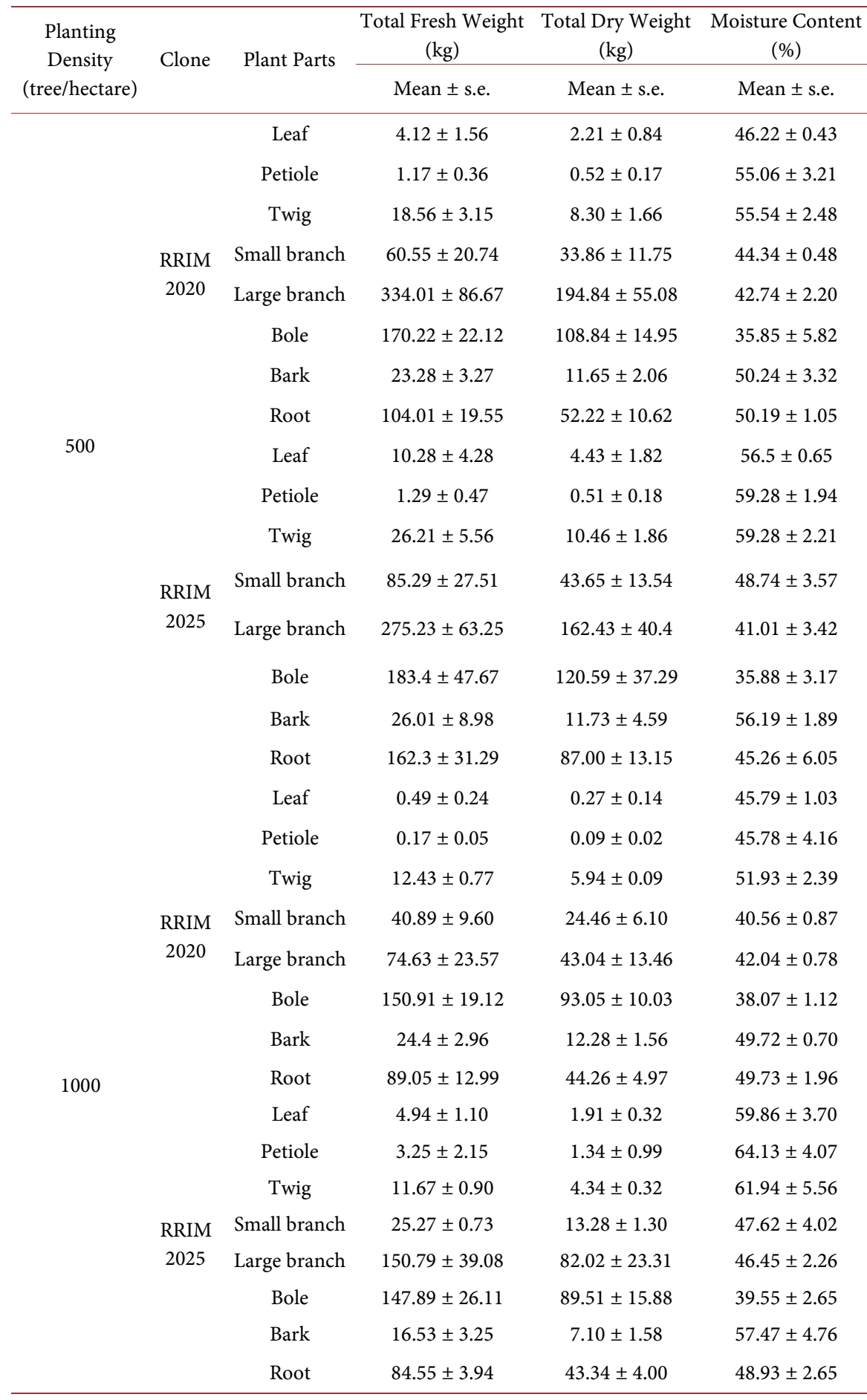


(b)

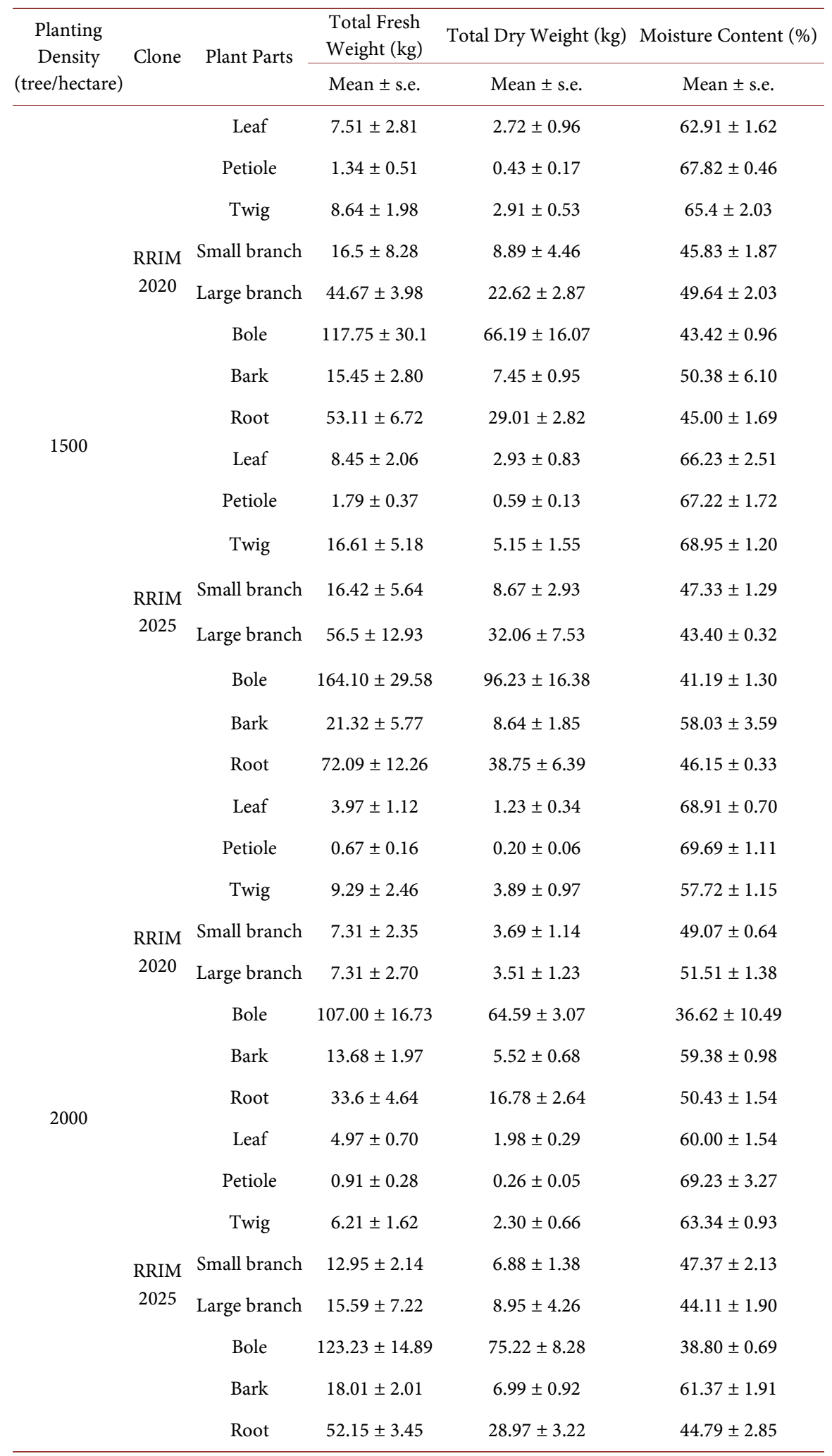

and TDW for both clones were observed in large branch, while the lowest values were observed in petiole. The highest MC was in twig and the lowest was in bole. 
In 1000 plants/ha planting density, for clone RRIM 2020 the highest TFW and TDW were seen in bole and the lowest were in petiole. The highest MC for this clone was in twig while the lowest was in bole. On the other hand for clone RRIM 2025 the highest TFW was in large branch while the highest TDW was in bole. The lowest values for TFW and TDW were both found in petiole. The highest MC for this clone was in petiole and the lowest was in bole.

In 1500 plants/ha planting density for clone RRIM 2020, the highest TFW and TDW were found in bole and the lowest were in petiole. The opposite happened for MC values where the highest MC was in petiole and the lowest was in bole. For clone RRIM 2025 the same pattern for TFW and TDW were observed; only slight different for MC values where the highest was seen in twig and the lowest was in bole. Finally for 2000 plants/ha planting density, both clones showed the same pattern of the highest TFW and TDW in bole and the lowest in petiole. The opposite pattern was observed for MC where the highest value was in petiole and the lowest value was in bole.

Carbon concentration in plant parts of RRIM 2020 and RRIM 2025 planted in four planting densities; 500, 1000, 1500 and 2000 plants/hectare is given in Table 2. The highest percentage of carbon is observed mostly in leaf while the lowest is

Table 2. Carbon concentration in plant parts of RRIM 2020 and RRIM 2025 in the different planting densities.

\begin{tabular}{|c|c|c|c|c|c|}
\hline \multirow{2}{*}{$\begin{array}{c}\text { Planting } \\
\text { density } \\
\text { (plants/ha) }\end{array}$} & \multirow{2}{*}{ Clone } & \multicolumn{4}{|c|}{ Plant parts } \\
\hline & & Leaf (\%) & Petiole (\%) & Twig (\%) & Small branch (\%) \\
\hline \multirow[t]{2}{*}{500} & RRIM 2020 & $53.26 \pm 0.15$ & $50.29 \pm 0.12$ & $49.11 \pm 0.30$ & $47.60 \pm 0.10$ \\
\hline & RRIM 2025 & $52.45 \pm 0.12$ & $51.66 \pm 0.08$ & $50.68 \pm 0.18$ & $49.42 \pm 0.12$ \\
\hline \multirow[t]{2}{*}{1000} & RRIM 2020 & $53.18 \pm 0.27$ & $51.93 \pm 0.20$ & $50.50 \pm 0.19$ & $48.23 \pm 0.12$ \\
\hline & RRIM 2025 & $52.01 \pm 0.25$ & $51.62 \pm 0.10$ & $50.06 \pm 0.11$ & $48.56 \pm 0.15$ \\
\hline \multirow[t]{2}{*}{1500} & RRIM 2020 & $52.41 \pm 0.14$ & $50.80 \pm 0.30$ & $50.12 \pm 0.20$ & $48.58 \pm 0.11$ \\
\hline & RRIM 2025 & $52.68 \pm 0.21$ & $51.36 \pm 0.23$ & $50.50 \pm 0.10$ & $48.79 \pm 0.12$ \\
\hline \multirow[t]{2}{*}{2000} & RRIM 2020 & $52.49 \pm 0.26$ & $52.83 \pm 0.10$ & $51.08 \pm 0.17$ & $48.97 \pm 0.07$ \\
\hline & RRIM 2025 & $52.58 \pm 0.12$ & $51.62 \pm 0.16$ & $50.48 \pm 0.13$ & $48.95 \pm 0.13$ \\
\hline \multirow{2}{*}{$\begin{array}{c}\text { Planting } \\
\text { density } \\
\text { (plants/ha) }\end{array}$} & \multirow[b]{2}{*}{ Clone } & \multicolumn{4}{|c|}{ Plant parts } \\
\hline & & $\begin{array}{c}\text { Large branch } \\
(\%)\end{array}$ & Bole (\%) & Bark (\%) & Root (\%) \\
\hline \multirow[t]{2}{*}{500} & RRIM 2020 & $47.76 \pm 0.09$ & $48.00 \pm 0.11$ & $47.91 \pm 0.37$ & $46.92 \pm 0.19$ \\
\hline & RRIM 2025 & $48.75 \pm 0.19$ & $48.51 \pm 0.23$ & $48.37 \pm 0.25$ & $48.04 \pm 0.21$ \\
\hline \multirow[t]{2}{*}{1000} & RRIM 2020 & $48.37 \pm 0.18$ & $48.05 \pm 0.13$ & $49.13 \pm 0.16$ & $47.62 \pm 0.12$ \\
\hline & RRIM 2025 & $48.53 \pm 0.13$ & $48.51 \pm 0.14$ & $48.52 \pm 0.13$ & $48.02 \pm 0.11$ \\
\hline \multirow[t]{2}{*}{1500} & RRIM 2020 & $48.52 \pm 0.10$ & $48.44 \pm 0.12$ & $48.62 \pm 0.24$ & $46.67 \pm 0.19$ \\
\hline & RRIM 2025 & $48.25 \pm 0.15$ & $48.56 \pm 0.12$ & $48.60 \pm 0.16$ & $47.79 \pm 0.18$ \\
\hline \multirow[t]{2}{*}{2000} & RRIM 2020 & $48.98 \pm 0.09$ & $48.49 \pm 0.13$ & $47.99 \pm 0.37$ & $47.95 \pm 0.21$ \\
\hline & RRIM 2025 & $48.68 \pm 0.05$ & $48.51 \pm 0.08$ & $48.37 \pm 0.37$ & $46.83 \pm 0.35$ \\
\hline
\end{tabular}


seen in root. ANOVA and Duncan's multiple range test for carbon concentration in plant parts of RRIM 2020 and RRI 2025 are given in Supplementary Table S1. The results showed significant different among carbon concentration in plant parts for both clones in all planting density. The highest carbon concentration was shown in leaf and the lowest in root, for both clones in all four densities.

Total content of carbon in plant parts is shown in Supplementary Table S2. The value is calculated by multiplying carbon concentration with the total dry weight of each plant parts. For 500 plants/ha density the highest carbon content is observed in large branch, while for the rest of planting densities the highest carbon is calculated in clear bole. ANOVA and Duncan's multiple range test for total content of carbon in plant parts of RRIM 2020 and RRI 2025 are given in Supplementary Table S3. The results showed significant different among total content of carbon in plant parts for both clones in all planting density. The highest content of carbon was shown in large branch for 500 plants/ha density and in bole for 1000, 1500 and 2000 plants/ha densities, for both clones. The lowest carbon content was evidenced in leaf, petiole and twig for both clones planted in all four densities. ANOVA and Duncan's multiple range test for total content of carbon in RRIM 2020 and RRIM 2025, comparing different densities are given in Supplementary Table S4. In general, the highest carbon content for all plant parts and whole tree was mainly found at 500 plants/ha density while the lowest was recorded at 2000 plants/ha density.

Pearson correlation coefficients of carbon content in plant parts and per whole tree are calculated and given in Supplementary Tables S5(a)-(d). The reason for analysis is to determine existence of correlation and subsequently derive regression equation for the strongly correlated variables. The equation is useful for future estimation of total carbon content by getting the exact carbon content value for only one part of tree, e.g. leaf collected during wintering phase of rubber tree could be used to estimate total carbon per whole tree. For RRIM 2020, the strongest correlations between plant part and total carbon per whole tree were found with large branch (in 500 plant/ha), small branch (in 1000 plant/ha) and leaf (in 1500 and 2000 plants/ha). For RRIM 2025, the strongest correlations were observed with small branch (in 500 and 1000 plants/ha), bole (1500 plants/ha) and root (2000 plants/ha). Regression plot and equation for the relationship between carbon content in plant parts and whole tree are derived from curve estimation function in SPSS and shown in Supplementary Figure S1-S8. The most fitted curve equation could be suggested as follows;

For RRIM 2020 at 500 plants/ha

$$
W=1.286 L b+77.381
$$

For RRIM 2020 at 1000 plants/ha

$$
W=0.552 S b^{2}-12.231 S b+165.225
$$

For RRIM 2020 at 1500 plants/ha 


$$
W=23.645 L+33.903
$$

For RRIM 2020 at 2000 plants/ha

$$
W=24.756 L+32.350
$$

For RRIM 2025 at 500 plants/ha

$$
W=-0.120 S b^{2}+9.427 S b+77.794
$$

For RRIM 2025 at 1000 plants/ha

$$
W=3.879 S b^{2}-31.218 S b+154.983
$$

\section{For RRIM 2025 at 1500 plants/ha}

$$
W=-0.007 B^{2}+2.614 B-12.169
$$

For RRIM 2025 at 2000 plants/ha

$$
W=0.304 R^{2}-5.875 R+85.96
$$

where;

$W=$ Total carbon per whole tree;

$L b=$ Carbon content in large branch;

$S b=$ Carbon content in small branch;

$L=$ Carbon content in leaf;

$B=$ Carbon content in bole;

$R=$ Carbon content in root.

Trend analysis for carbon content (in plant parts and per whole tree) of RRIM 2020 in the proportionate increment of density (500, 1000, 1500 and 2000 plants/ha) is given in Supplementary Table S6. Linear, quadratic and cubic trends were observed for total carbon per tree. The regression plot and equation are shown in Supplementary Figure S9. From the regression plot the relationship between carbon content per tree and density is in negative pattern whereby an increase in density will result in decrease carbon content per tree. The most fitted regression equation derived from the relationship could be suggested as follows;

$$
W=0.00007002 D^{2}-0.272 D+314.286
$$

where;

$W=$ Total carbon per tree;

$D=$ Planting density.

For RRIM 2025 the trend analysis is given in Supplementary Table S7, while the regression plot and equation are given in Supplementary Figure S10. Linear, quadratic and cubic trends were also observed for total carbon per tree. The relationship between carbon content per tree and density is negatively related whereby an increase in density will result in decrease carbon content per tree. The most fitted regression equation derived from the relationship could be suggested as follows;

$$
W=-0.0000001047 D^{3}-0.699 D+462.459
$$

Total content of carbon per hectare was calculated by multiplying carbon 
content per tree with number of tree stands and the results are shown in Supplementary Table S8 under the column "Whole tree". The value was calculated by assuming zero number of tree deaths in all plant densities. ANOVA and Duncan's multiple range test for total content of carbon per hectare in RRIM 2020 and RRIM 2025, comparing different densities are given in Supplementary Table S9. The highest carbon content per hectare was evidenced in RRIM 2025 planted in 1500 plants/ha density $(140,355 \pm 9888 \mathrm{~kg})$, while the lowest in RRIM 2020 planted in 2000 plants/ha density $(96,542 \pm 3718 \mathrm{~kg})$. Student t-test results in Supplementary Table S10 comparing total carbon per hectare between the two clones showed no significant difference at low density of 500 and 1000 plants/ha, however the difference was significant at high density of 1500 and 2000 plants/ha. RRIM 2025 had consistently shown to have higher total carbon per hectare compared to RRIM 2020.

\section{Discussion}

Carbon sequestration through establishments of rubber forest plantation (RFP) is a good option where rubber growers can earn income from latex and timber harvestings while at the same time carbon in the atmosphere could be sequestered in the plant parts of rubber tree. RFP concept that maintains natural cover cropping using weed species also contributes to the carbon storage. To date a total of 50 weed species belonging to 22 families were identified in various rubber forest plantations throughout Malaysia since 2007 [17]. In addition, an area conserving element of flora and fauna, called special management zone is created in RFP to further employ the concept of forest as a carbon sink.

There is a question on whether the carbon sequestered through forest plantation will be forever locked in or will eventually move to other carbon pool. For example when trees are chopped down the carbon will be released back to the atmosphere through burning of woody tissue. In the case of wood being converted to furniture, the carbon storage might be as long as the lifetime of the furniture, however it might ultimately be released back to the air when furniture is disposed. The only way to ensure continuous sequestration of carbon is through systematic replenishment of rubber forest plant materials. For example the forest itself need to be planted in various phases to ensure that trees are not uniformly the same age so that harvestings will not happen all at once.

Summary on total fresh weight (TFW), total dry weight (TDW) and total carbon (TC) gives a general overview on biomass information and pattern of carbon disposition. At 500 plants/ha density, mostly both clones have the highest TFW, TDW and TC in large branches. As density goes higher, the pattern shifted towards clear bole. This gives indication that the tree crown grew bigger in less dense planting in order to maximize the photosynthesis activity, while in denser planting the competition among trees increases and forces them to grow taller in order to reach for more light source and hence the clear bole mass becomes greater. 
In general carbon is evidently sequestered the most in woody parts of tree, which in this case are large branch and trunk. This is explained by the abundant amount of lignocellulosic materials that give the hard and strength properties for these woody plant parts. In addition, large branch and clear bole have the highest biomass weight compared to other plant parts; therefore carbon would be sequestered the most here. When compared with carbon concentration data in each plant parts, a different pattern is observed where leaf was found to have the highest carbon concentration. This could be explained by the highest concentration of lignin found in leaf [18]. Another possible explanation for this is the presence of photosynthetic activity in leaf whereby carbon dioxide is captured from the air and converted to carbohydrate molecules.

Total content of carbon was found highest in large branch at 500 plants/ha and in bole at 1000, 1500 and 2000 plant/ha. This could be explained by the high biomass weight measured for large branch at 500 plants/ha and bole at the rest of plant densities. When comparing densities, it was found that carbon content was highest and statistically significant at 500 plants/ha, for majority of plant parts and whole tree. This showed that by increasing plant density it will definitely results in significant reduction of biomass and carbon content. In simpler term, rubber tree became smaller in size. Contrary to the amount of total carbon sequestered per hectare, increased density will give higher sequestration of carbon due to increase number of tree stands; the highest carbon sequestered per hectare was found in RRIM 2025 at 1500 plants/ha.

When recommending the most suitable plant density to rubber growers, two main things shall be taken into account; the latex and wood volume. If trees are to be planted in denser plant density, the girth of tree trunk will be smaller and thus tree maturity is delayed-the readiness for open tapping. Therefore there is a high probability that trees are delayed tapping or cannot even be tapped due to a very small girthing. On the aspect of wood volume, planting in denser density will results in taller, but thinner trunk. Even though biomass weight can still be maintained in denser density, the diameter of sawn timber will be reduced and thus affect the overall number of recovery for 4 " $\times 4$ " and 1 " $\times 1$ " sized sawn timber. Therefore planting at 500 plants/ha is still recommended as this gives higher sawn timber recovery and thus benefits the timber industry.

The best fitted regression equations for carbon content in plant parts and total carbon per whole tree is useful for future work involving estimation of carbon sequestration in rubber tree for these two clones; RRIM 2020 and RRIM 2025. The equations are specifically targeted for untapped rubber trees of RRIM 2020 and RRIM 2025, since diameter of the trunk will increase proportionately with the rest of tree parts. Compared with tapped rubber tree, the girth increment will reduce after tree is opened for tapping, about 1 to $3 \mathrm{~cm}$ increment per year, while girth increment for untapped tree is around 8 to $10 \mathrm{~cm}$ per year [19]. Therefore the equations are only applied to untapped rubber tree for carbon content estimation. The advantage of using these equations is that tree will not have to be cut in order to carry out biomass estimation, rather only one part of 
tree is taken for biomass weight measurement. For instance only the small branches are pruned, or only leaves are collected (during tree wintering) to ascertain the exact amount of carbon content.

Using 500 plants/ha density and RRIM 2025 as planting material the total carbon sequestered from rubber trees of eleven-year old age can reach up to $107,282 \mathrm{~kg} / \mathrm{ha}$. Malaysia in the context of carbon market project is listed as developing country, termed as non-Annex 1 country. International emissions trading allows developed countries to trade their commitments under the Kyoto Protocol, whereby they can trade emissions quotas among themselves, and can also receive credit for financing emissions reductions in developing countries. Developing countries in general do not have binding targets under the Kyoto Protocol, but are still committed under the treaty to reduce their emissions. Under the Protocol, emissions of developing countries are allowed to grow in accordance with their development needs [20]. In accordance to that, establishment of rubber forest plantation is seen as a perfect platform to venture into Clean Development Mechanism (CDM) project since it is considered lower in cost when compared to any reduction of carbon output projects in developed countries. If Malaysia captures two percent of the CDM market this could equal to US\$120 to 400 million in revenue [21]. The CDM project which any company would venture into must support the sustainable development policies of Malaysia, following the national CDM criteria approved by the National Committee on CDM (NCCDM) [22].

\section{Conclusion}

Rubber forest plantation is a good carbon sink where source of carbon sequestration comes from rubber trees, soil, cover crops and special management zone. Planting density with 500 plant/ha shall be employed in the forest establishment so that carbon can be sequestered in the highest amount in rubber plant parts as to support the timber industry. Carbon trading is a potential income generating activity which Malaysia could consider participating, specifically for establishment of rubber forest plantation projects.

\section{Acknowledgements}

The authors would like to extend gratitude to the Malaysian Rubber Board for funding the research. We would also like to thank all the assistance given by our supporting staffs; Zuraidah, Zailiza, Diyana and Shukri.

\section{Conflicts of Interest}

The authors declare no conflicts of interest regarding the publication of this paper.

\section{References}

[1] Environmental Initiative (1999) Earth Systems. College of Arts and Sciences, Lehigh 
University, Bethlehem. http://ei.lehigh.edu/eli/cc/support/pdf/EarthSystem_PrintVersion.pdf

[2] Forster, P., Ramawamy, V., Artaxo, P., Berntsen, T., Betts, R., Fahey, D.W., Haywood, J., Lean, J., Lowe, D.C., Myhre, G., Nganga, J., Prinn, R., Raga, G., Schulz, M. and Van Dorland, R. (2007) Changes in Atmospheric Constituents and in Radiative Forcing. In: Solomon, S., et al., Eds., Climate Change 2007: The Physical Basis. Contribution of Working Group I to the Fourth Assessment Report of the Intergovernmental Panel on Climate Change, Cambridge University Press, Cambridge, 129-234.

[3] Prentice, I.C., Farquhar, G.D., Fasham, M.J.R., Goulden, M.L., Heimann, M., Jaramillo, V.J., Kheshgi, H.S., LeQuéré, C., Scholes, R.J. and Wallace, D.W.R. (2001) The Carbon Cycle and Atmospheric Carbon Dioxide. In: Houghton, J.T., Ding, Y., Griggs, D.J., Noguer, M., van der Linden, P.J., Dai, X., Maskell, K. and Johnson, C.A., Eds., Climate Change 2001: The Scientific Basis. Contributions of Working Group I to the Third Assessment Report of the Intergovernmental Panel on Climate Change, Cambridge University Press, Cambridge, 185-237.

[4] Petty, G.W. (2004) A First Course in Atmospheric Radiation. Sundog Publishing, Madison, 229-251.

[5] Commonwealth of Learning (2005) Green Teacher: Module I: Basics of Ecology and Life Support Systems. Commonwealth of Learning, Centre for Environment Education, India. 46-53. http://oasis.col.org/handle/11599/734

[6] Herzog, H.J. and Golomb, D. (2004) Carbon Capture and Storage from Fossil Fuel Use. In: Cleveland, C.J., Ed., Encyclopedia of Energy, Elsevier Science Inc., New York, 277-287. https://doi.org/10.1016/B0-12-176480-X/00422-8

[7] Ecological Society of America (2000) The Role of Forests in Reducing Atmospheric Carbon. Ecological Society of America, Washington DC. http://www.esa.org

[8] Tian, H., Melillo, J.M., Kicklighter, D.W., McGuire, A.D., Helfrich, J.V.K., Moore B. and Vorosmarty, C.J. (1998) Effect of Interannual Climate Variability on Carbon Storage in Amazonian Ecosystems. Nature, 396, 664-667. https://doi.org/10.1038/25328

[9] Tian, H., Melillo, J.M., Kicklighter, D.W., McGuire, A.D., Helfrich, J.V.K., Moore B. and Vorosmarty, C.J. (2000) Climatic and Biotic Controls on Annual Carbon Storage in Amazonian Ecosystems. Global Ecology and Biogeography, 9, 315-335. https://doi.org/10.1046/j.1365-2699.2000.00198.x

[10] Prentice, I. and Lloyd, J. (1998) C-Quest in the Amazon Basin. Nature, 396, 619-620. https://doi.org/10.1038/25224

[11] Phillips, O.L., Malhi, Y., Higuchi, N.W.F., Laurance, P.V., Nunez, R.M., Vasquez, S., Laurance, G., Ferreira, L.V., Stern, M., Brown, S. and Grace, J. (1998) Changes in the Carbon Balance of Tropical Forests: Evidence from Long-Term Plots. Science, 282, 439-442.

[12] Malhi, Y., Nobre, A.D., Grace, J., Kruijt, B., Pereira, M.G.P., Culf, A. and Scott, S. (1998) Carbon Dioxide Transfer over a Central Amazonian Rain Forest. Journal of Geophysical Research Atmospheres, 103, 31593-31612. https://doi.org/10.1029/98JD02647

[13] Grace, J., Lloyd, J., McIntyre, J., Miranda, A.C., Meir, P., Miranda, H.S., Nobre, C., Moncrieff, J., Massheder, J., Malhi, Y., Wright, I. and Gash, J. (1995) Carbon-Dioxide Uptake by an Undisturbed Tropical Rain-Forest in Southwest Amazonia, 1992 to 1993. Science, 270, 778-780.

https://doi.org/10.1126/science.270.5237.778 
[14] Dixon, R.K., Brown, S., Houghton, R.A., Solomon, A.M., Trexler, M.C. and Wisniewski, J. (1994) Carbon Pools and Flux of Global Forest Ecosystems. Science, 263, 185-190. https://doi.org/10.1126/science.263.5144.185

[15] Melillo, J.M., McGuire, A.D., Kicklighter, D.W., Moore, B., Vorosmarty, C.J. and Schloss, A.L. (1993) Global Climate-Change and Terrestrial Net Primary Production. Nature, 363, 234-240. https://doi.org/10.1038/363234a0

[16] Rasib, A.W., Ibrahim, A.L., Cracknell, A.P., Md. Noor, N.S., Kassim, A.R., Hamzah, K.A., Abdullah Sani, M.F. and Huey, T.T. (2010) Integration of Biometric and Remote Sensing Techniques for Estimation of Net Ecosystem Productivity in Tropical Rain Forest. 31 st Asian Conference on Remote Sensing, Vol. 1, Hanoi, 1-5 November 2010, 745-750.

[17] Goh, S.S. (2009) Biodiversity in Rubber Forest Plantation: A Compendium of Weeds Collection. Malaysian Rubber Board, Kuala Lumpur, 11.

[18] Mohamad Razar, R. and Mohd. Aris, M.N. (2011) The Study on Lignin Concentration in Different Plant Parts of Six Hevea Species in Relation to Biofuel Production. International Tree Breeding Workshop, Bahia, 4-7 April 2011, 12.

[19] Lembaga Getah Malaysia (2003) LGM Planting Recommendations 2003. Malaysian Rubber Board, Kuala Lumpur, 24.

[20] UNFCCC (1998) Kyoto Protocol to the United Nations Framework Convention on Climate Change. http://unfccc.int/kyoto_protocol/items/2830.php

[21] Sorensen, M.P. (2003) The Carbon Market. What Is It? And What Is the Role of CDM Project? Proceedings of CDM Colloquium. Pusat Tenaga Malaysia, Kuala Lumpur.

[22] Amran, A., Zainuddin, Z. and Zailani, S.H.M. (2012) Carbon Trading in Malaysia: Review of Policies and Practices. Sustainable Development, 21, 183-192.

https://doi.org/10.1002/sd.1549 


\section{Supplementary Files}

Table S1. ANOVA and Duncan's grouping for carbon concentration in plant parts.

\begin{tabular}{|c|c|c|c|c|c|c|c|c|c|c|c|c|}
\hline \multirow{2}{*}{ Clone } & \multirow{2}{*}{$\begin{array}{c}\text { Density } \\
\text { (plants/hectare) }\end{array}$} & \multicolumn{3}{|c|}{ ANOVA } & \multicolumn{8}{|c|}{ Duncan's grouping } \\
\hline & & df & MS & VR & Leaf & Petiole & Twig & $\begin{array}{l}\text { Small } \\
\text { branch }\end{array}$ & $\begin{array}{l}\text { Large } \\
\text { branch }\end{array}$ & Bole & Bark & Root \\
\hline \multirow{4}{*}{$\begin{array}{l}\text { RRIM } \\
2020\end{array}$} & 500 & 7 & 50.778 & $102.148^{*}$ & A & B & $\mathrm{C}$ & $\mathrm{D}$ & $\mathrm{D}$ & $\mathrm{D}$ & $\mathrm{D}$ & $\mathrm{E}$ \\
\hline & 1000 & 7 & 49.662 & $129.537^{\star}$ & A & B & $\mathrm{C}$ & $\mathrm{E}$ & $\mathrm{E}$ & $\mathrm{EF}$ & $\mathrm{D}$ & $\mathrm{F}$ \\
\hline & 1500 & 7 & 37.411 & $89.723^{*}$ & A & B & C & D & $\mathrm{D}$ & $\mathrm{D}$ & D & E \\
\hline & 2000 & 7 & 47.603 & $101.243^{\star}$ & A & A & B & $\mathrm{C}$ & $\mathrm{C}$ & $\mathrm{CD}$ & $\mathrm{D}$ & $\mathrm{D}$ \\
\hline \multirow{4}{*}{$\begin{array}{l}\text { RRIM } \\
2025\end{array}$} & 500 & 7 & 33.119 & $84.178^{*}$ & A & B & $\mathrm{C}$ & $\mathrm{D}$ & $\mathrm{E}$ & $\mathrm{EF}$ & $\mathrm{EF}$ & $\mathrm{F}$ \\
\hline & 1000 & 7 & 29.233 & $114.476^{*}$ & A & A & B & $\mathrm{C}$ & $\mathrm{C}$ & $\mathrm{C}$ & $\mathrm{C}$ & $\mathrm{D}$ \\
\hline & 1500 & 7 & 36.338 & $112.108^{*}$ & A & B & C & $\mathrm{D}$ & $\mathrm{EF}$ & $\mathrm{DE}$ & $\mathrm{DE}$ & $\mathrm{F}$ \\
\hline & 2000 & 7 & 43.412 & $84.628^{*}$ & A & B & C & D & D & D & D & E \\
\hline
\end{tabular}

Note: df: Degree of freedom; MS: Mean square; VR: Variance ratio; ${ }^{*}$ : significant at $\mathrm{p}<0.05$. Plant parts with the same alphabet are in the same homogenous subset for mean carbon concentration.

Table S2. Total content of carbon in plant parts of RRIM 2020 and RRIM 2025 in the different planting densities.

\begin{tabular}{|c|c|c|c|c|c|}
\hline \multirow{2}{*}{$\begin{array}{c}\text { Planting } \\
\text { density } \\
\text { (plants/ha) }\end{array}$} & \multirow{2}{*}{ Clone } & \multicolumn{4}{|c|}{ Plant parts } \\
\hline & & Leaf (kg) & Petiole (kg) & Twig (kg) & Small branch $(\mathrm{kg})$ \\
\hline \multirow[t]{2}{*}{500} & RRIM 2020 & $1.18 \pm 0.19$ & $0.26 \pm 0.04$ & $4.06 \pm 0.33$ & $16.14 \pm 2.40$ \\
\hline & RRIM 2025 & $2.32 \pm 0.41$ & $0.26 \pm 0.04$ & $5.30 \pm 0.40$ & $21.60 \pm 2.88$ \\
\hline \multirow[t]{2}{*}{1000} & RRIM 2020 & $0.14 \pm 0.03$ & $0.05 \pm 0.00$ & $3.00 \pm 0.03$ & $11.82 \pm 1.28$ \\
\hline & RRIM 2025 & $0.99 \pm 0.07$ & $0.69 \pm 0.22$ & $2.17 \pm 0.07$ & $6.44 \pm 0.26$ \\
\hline \multirow[t]{2}{*}{1500} & RRIM 2020 & $1.43 \pm 0.21$ & $0.22 \pm 0.04$ & $1.46 \pm 0.12$ & $4.31 \pm 0.92$ \\
\hline & RRIM 2025 & $1.55 \pm 0.19$ & $0.30 \pm 0.03$ & $2.60 \pm 0.33$ & $4.22 \pm 0.61$ \\
\hline \multirow[t]{2}{*}{2000} & RRIM 2020 & $0.64 \pm 0.08$ & $0.11 \pm 0.01$ & $1.99 \pm 0.22$ & $1.81 \pm 0.24$ \\
\hline & RRIM 2025 & $1.04 \pm 0.06$ & $0.14 \pm 0.01$ & $1.16 \pm 0.14$ & $3.36 \pm 0.28$ \\
\hline \multirow{2}{*}{$\begin{array}{c}\text { Planting } \\
\text { ]density } \\
\text { (plants/ha) }\end{array}$} & \multirow[b]{2}{*}{ Clone } & \multicolumn{4}{|c|}{ Plant parts } \\
\hline & & Large branch $(\mathrm{kg})$ & Bole (kg) & Bark (kg) & Root (kg) \\
\hline \multirow[t]{2}{*}{500} & RRIM 2020 & $93.04 \pm 11.22$ & $52.20 \pm 2.99$ & $5.58 \pm 0.42$ & $24.58 \pm 2.19$ \\
\hline & RRIM 2025 & $79.21 \pm 8.43$ & $58.47 \pm 7.69$ & $5.72 \pm 0.98$ & $41.67 \pm 2.54$ \\
\hline \multirow[t]{2}{*}{1000} & RRIM 2020 & $20.84 \pm 2.78$ & $44.71 \pm 2.05$ & $6.04 \pm 0.34$ & $21.10 \pm 1.05$ \\
\hline & RRIM 2025 & $39.71 \pm 4.77$ & $43.50 \pm 3.37$ & $3.45 \pm 0.33$ & $20.81 \pm 0.81$ \\
\hline \multirow[t]{2}{*}{1500} & RRIM 2020 & $10.98 \pm 0.60$ & $32.02 \pm 3.27$ & $3.63 \pm 0.21$ & $13.55 \pm 0.59$ \\
\hline & RRIM 2025 & $15.43 \pm 1.50$ & $46.73 \pm 3.38$ & $4.21 \pm 0.39$ & $18.53 \pm 1.31$ \\
\hline \multirow[t]{2}{*}{2000} & RRIM 2020 & $1.72 \pm 0.26$ & $31.33 \pm 0.68$ & $2.65 \pm 0.14$ & $8.02 \pm 0.51$ \\
\hline & RRIM 2025 & $4.35 \pm 0.88$ & $36.48 \pm 1.69$ & $3.37 \pm 0.18$ & $13.54 \pm 0.61$ \\
\hline
\end{tabular}

Note: Values calculated by multiplying carbon concentration with total dry weight of plant parts. 
Table S3. ANOVA and Duncan's grouping for total content of carbon in plant parts.

\begin{tabular}{|c|c|c|c|c|c|c|c|c|c|c|c|c|}
\hline \multirow[b]{2}{*}{ Clone } & \multirow{2}{*}{$\begin{array}{c}\text { Density } \\
\text { (plants/hecta) }\end{array}$} & \multicolumn{3}{|c|}{ ANOVA } & \multicolumn{8}{|c|}{ Duncan's grouping } \\
\hline & & $\mathrm{df}$ & MS & VR & Leaf & Petiole & Twig & $\begin{array}{l}\text { Small } \\
\text { branch }\end{array}$ & $\begin{array}{l}\text { Large } \\
\text { branch }\end{array}$ & Bole & Bark & Root \\
\hline \multirow{4}{*}{$\begin{array}{c}\text { RRIM } \\
2020\end{array}$} & 500 & 7 & 12757.656 & $58.398^{\star}$ & $\mathrm{E}$ & $\mathrm{E}$ & $\mathrm{DE}$ & $\mathrm{CD}$ & A & B & $\mathrm{DE}$ & $\mathrm{C}$ \\
\hline & 1000 & 7 & 2766.845 & $124.977^{*}$ & $\mathrm{E}$ & $\mathrm{E}$ & $\mathrm{DE}$ & $\mathrm{C}$ & B & A & $\mathrm{D}$ & B \\
\hline & 1500 & 7 & 1362.007 & $73.415^{*}$ & $\mathrm{CD}$ & $\mathrm{D}$ & $\mathrm{CD}$ & $\mathrm{C}$ & B & A & $\mathrm{CD}$ & B \\
\hline & 2000 & 7 & 1324.065 & $960.474^{*}$ & $\mathrm{D}$ & $\mathrm{D}$ & $\mathrm{C}$ & $\mathrm{C}$ & $\mathrm{C}$ & A & $\mathrm{C}$ & B \\
\hline \multirow{4}{*}{$\begin{array}{l}\text { RRIM } \\
2025\end{array}$} & 500 & 7 & 10642.384 & $48.504^{\star}$ & $\mathrm{E}$ & $\mathrm{E}$ & $\mathrm{E}$ & $\mathrm{D}$ & A & B & $\mathrm{E}$ & $\mathrm{C}$ \\
\hline & 1000 & 7 & 3819.642 & $72.806^{*}$ & $\mathrm{C}$ & $\mathrm{C}$ & $\mathrm{C}$ & $\mathrm{C}$ & A & A & $\mathrm{C}$ & B \\
\hline & 1500 & 7 & 2940.84 & $122.017^{*}$ & $\mathrm{C}$ & $\mathrm{C}$ & $\mathrm{C}$ & $\mathrm{C}$ & B & A & $\mathrm{C}$ & B \\
\hline & 2000 & 7 & 1808.354 & $291.475^{\star}$ & $\mathrm{D}$ & $\mathrm{D}$ & $\mathrm{D}$ & $\mathrm{C}$ & $\mathrm{C}$ & A & $\mathrm{C}$ & B \\
\hline
\end{tabular}

Note: ANOVA, df: Degree of freedom; MS: Mean square; VR: Variance ratio; ${ }^{*}$ : significant at $p<0.05$. Plant parts with the same alphabet are in the same homogenous subset for mean total content of carbon.

Table S4. ANOVA and Duncan's grouping for total content of carbon per tree in the different planting density.

\begin{tabular}{|c|c|c|c|c|c|c|c|c|}
\hline \multirow{2}{*}{ Clone } & \multirow{2}{*}{ Plant parts } & \multicolumn{3}{|c|}{ ANOVA } & \multicolumn{4}{|c|}{ Duncan's grouping } \\
\hline & & $\mathrm{df}$ & MS & VR & $500 \mathrm{t} / \mathrm{ha}$ & $1000 \mathrm{t} / \mathrm{ha}$ & $1500 \mathrm{t} / \mathrm{ha}$ & $2000 \mathrm{t} / \mathrm{ha}$ \\
\hline \multirow{9}{*}{ RRIM 2020} & Leaf & 3 & 3.946 & $14.727^{\star}$ & A & $\mathrm{C}$ & A & B \\
\hline & Petiole & 3 & 0.118 & $14.275^{\star}$ & A & B & A & B \\
\hline & Twig & 3 & 15.861 & $30.699^{*}$ & A & B & $\mathrm{C}$ & $\mathrm{C}$ \\
\hline & Small branch & 3 & 526.900 & $21.214^{\star}$ & A & B & $\mathrm{C}$ & $\mathrm{C}$ \\
\hline & Large branch & 3 & 20836.641 & $51.853^{\star}$ & A & B & $\mathrm{BC}$ & $\mathrm{C}$ \\
\hline & Bole & 3 & 1238.869 & $16.975^{\star}$ & A & B & $\mathrm{C}$ & $\mathrm{C}$ \\
\hline & Bark & 3 & 30.872 & $29.457^{\star}$ & A & A & B & $\mathrm{C}$ \\
\hline & Root & 3 & 666.535 & $34.085^{\star}$ & A & A & B & $\mathrm{C}$ \\
\hline & Whole tree & 3 & 52387.150 & $70.847^{\star}$ & A & B & $\mathrm{C}$ & $\mathrm{C}$ \\
\hline \multirow{9}{*}{ RRIM 2025} & Leaf & 3 & 4.590 & $7.268^{\star}$ & A & B & B & B \\
\hline & Petiole & 3 & 0.692 & $4.613^{*}$ & B & A & B & B \\
\hline & Twig & 3 & 37.508 & $42.380^{*}$ & A & B & B & $\mathrm{C}$ \\
\hline & Small branch & 3 & 879.649 & $33.378^{\star}$ & A & B & B & B \\
\hline & Large branch & 3 & 13195.661 & $45.398^{*}$ & A & B & $\mathrm{C}$ & $\mathrm{C}$ \\
\hline & Bole & 3 & 1010.374 & $3.974^{*}$ & A & B & A & B \\
\hline & Bark & 3 & 14.253 & $3.787^{\star}$ & A & B & $\mathrm{AB}$ & B \\
\hline & Root & 3 & 1845.242 & $66.727^{\star}$ & A & B & B & $\mathrm{C}$ \\
\hline & Whole tree & 3 & 51293.364 & $82.361^{\star}$ & A & B & $\mathrm{C}$ & $\mathrm{D}$ \\
\hline
\end{tabular}

Note: ANOVA, df: Degree of freedom; MS: Mean square; VR: Variance ratio; ns: Non-significant; ${ }^{*}$ significant at $\mathrm{p}<0.05$. Planting density with the same alphabet are in the same homogenous subset for mean total content of carbon per hectare. 
Table S5. (a) Pearson correlation coefficients among carbon content in plant parts of RRIM 2020 at 500 and 1000 plants/ha densities; (b) Pearson correlation coefficients among carbon content in plant parts of RRIM 2020 at 1500 and 2000 plants/ha densities; (c) Pearson correlation coefficients among carbon content in plant parts of RRIM 2025 at 500 and 1000 plants/ha densities; (d) Pearson correlation coefficients among carbon content in plant parts of RRIM 2025 at 1500 and 2000 plants/ha densities.

(a)

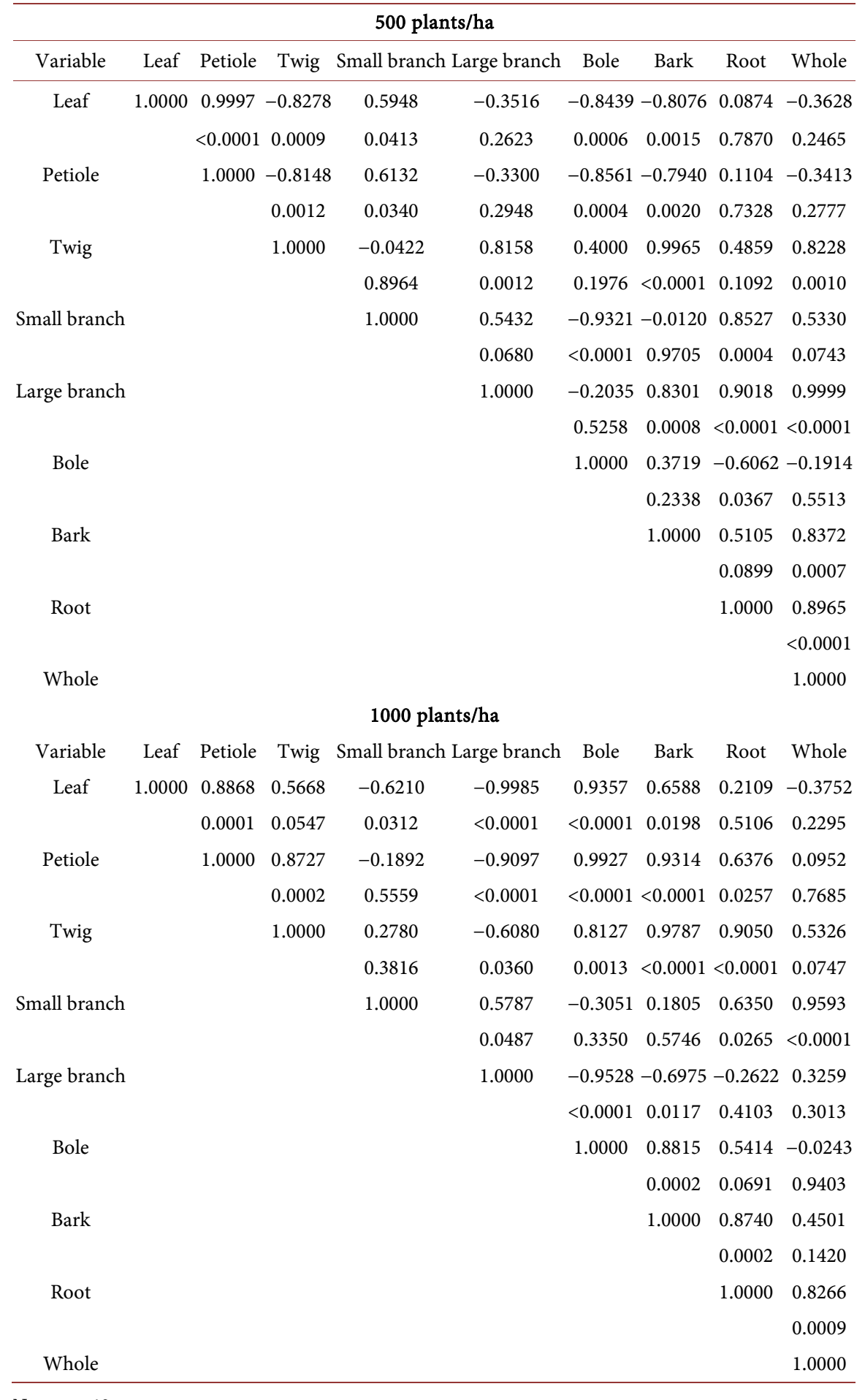

Note: $\mathrm{n}=12$. 
(b)

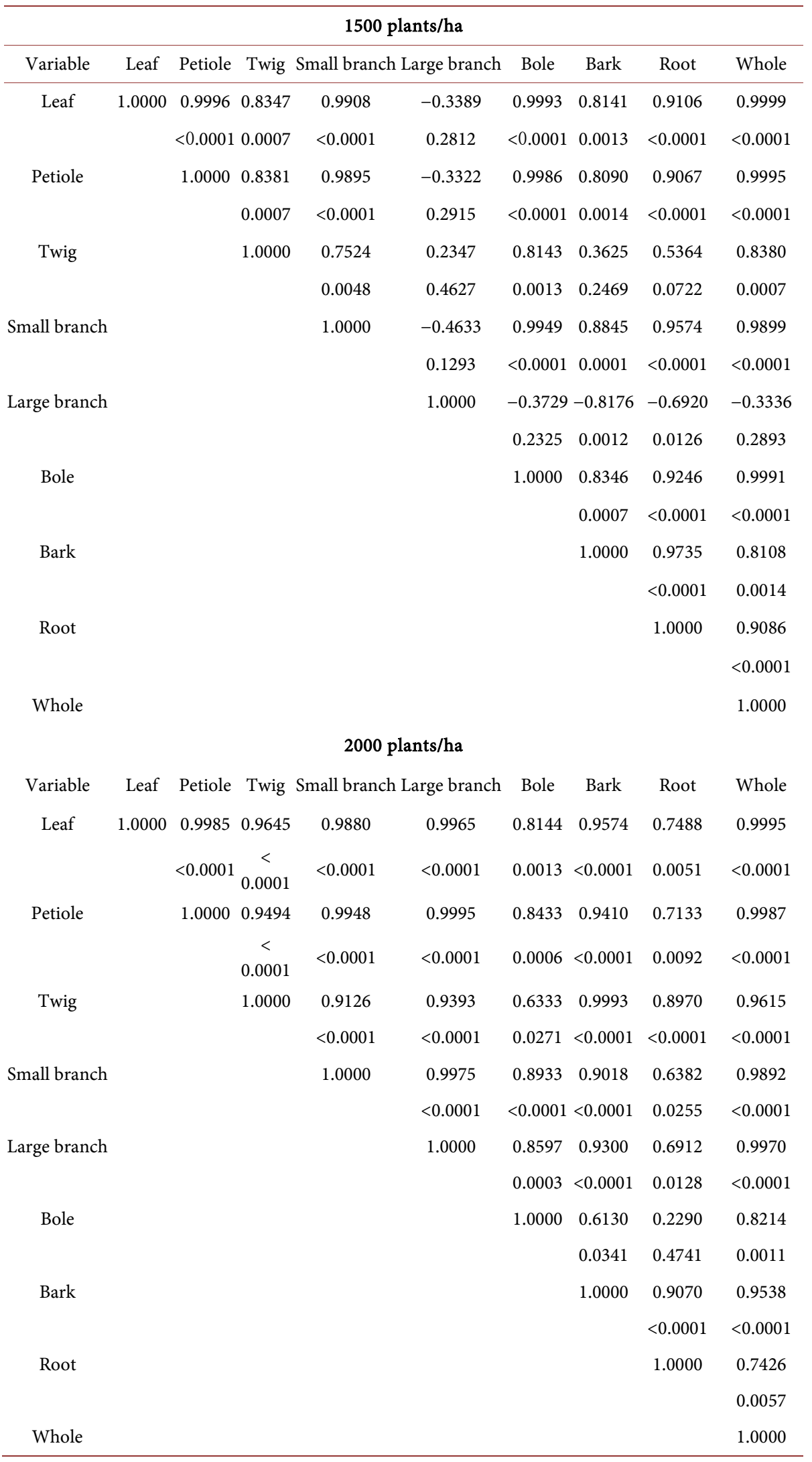

Note: $\mathrm{n}=12$. 
(c)

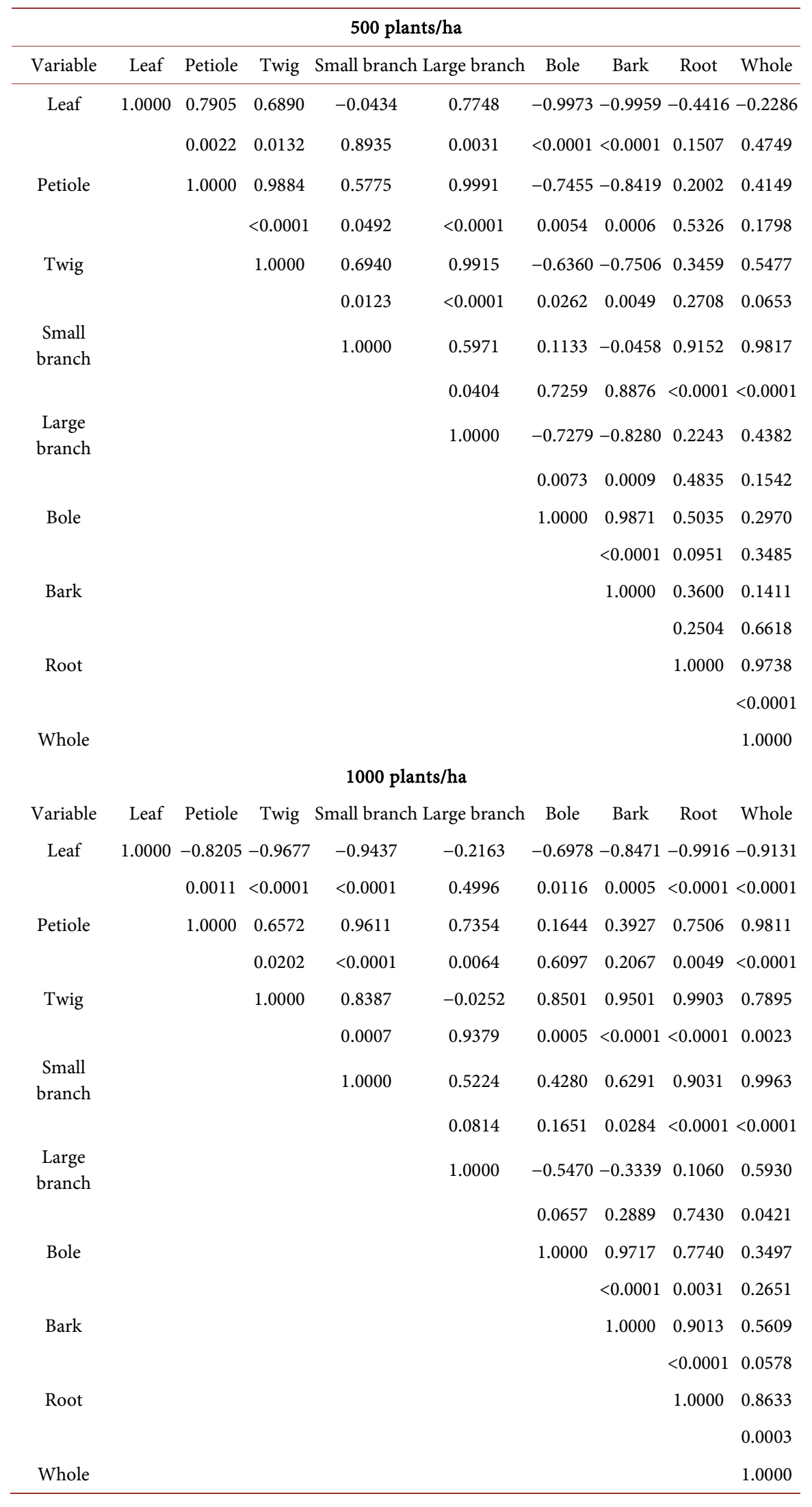

Note: $\mathrm{n}=12$. 
(d)

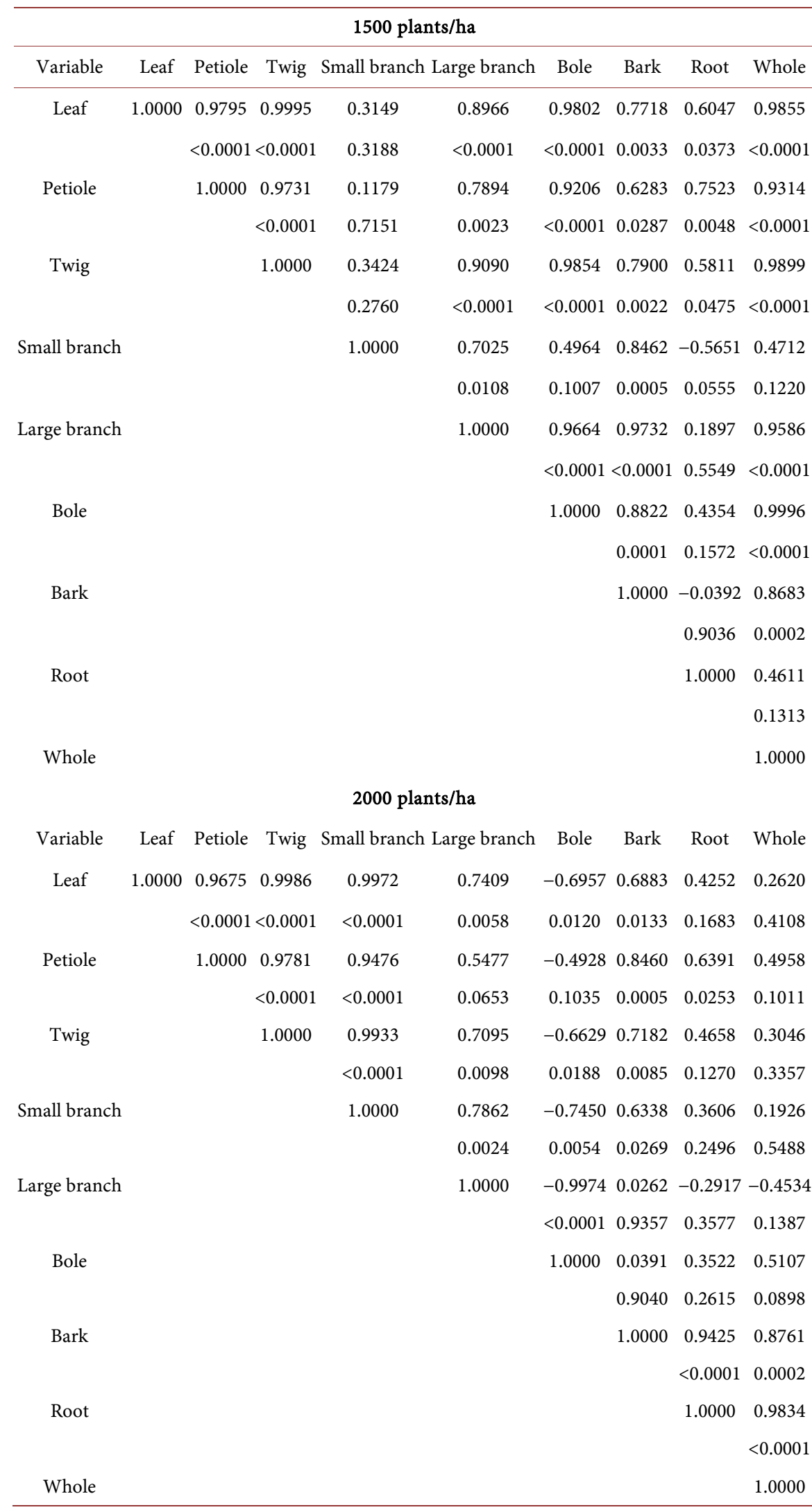

Note: $\mathrm{n}=12$. 


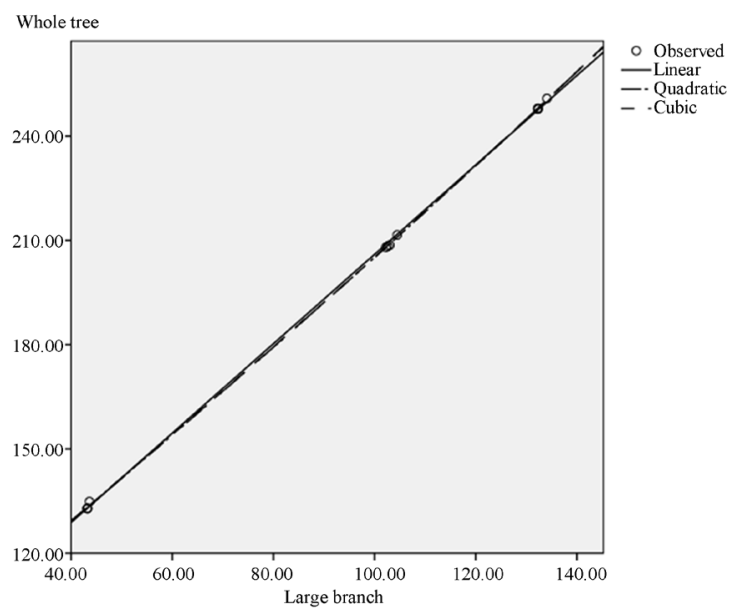

Model Summary and Parameter Estimates

Dependent Variable: Whole tree

\begin{tabular}{cccccccccc}
\hline \multirow{2}{*}{ Equation } & \multicolumn{1}{c}{ Model Summary } & \multicolumn{8}{c}{ Parameter Estimates } \\
& R Square & F & df1 & df2 & p-value & Constant & b1 & b2 & b3 \\
\hline Linear & 1.000 & 41745.986 & 1 & 10 & 0.000 & 77.381 & 1.286 & \\
Quadratic & 1.000 & 50137.262 & 2 & 9 & 0.000 & 81.617 & 1.164 & 0.001 & \\
Cubic & 1.000 & 50408.544 & 2 & 9 & 0.000 & 80.108 & 1.225 & 0.000 & $2.557 \mathrm{E}-006$ \\
& \multicolumn{1}{c}{ The independent variable is Large branch. } \\
\hline
\end{tabular}

Figure S1. Regression of total carbon in whole tree and large branch of RRIM 2020 planted at 500 plants/ha density.

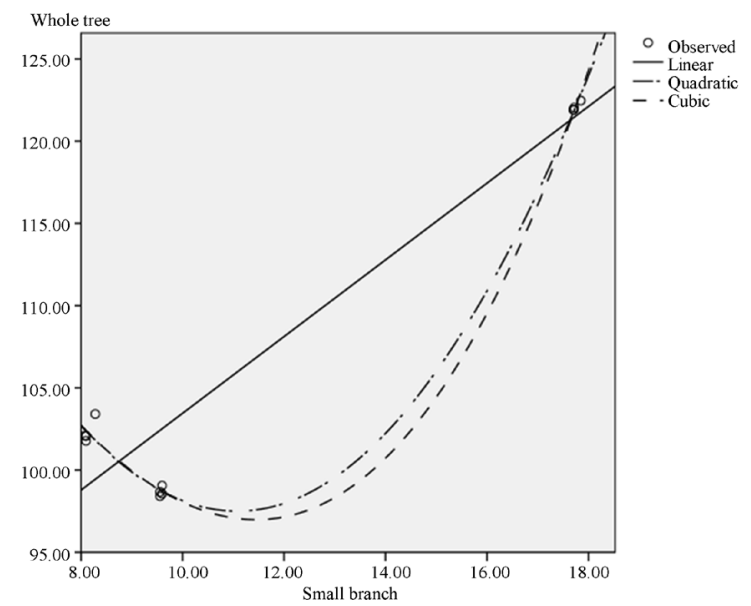

Model Summary and Parameter Estimates

Dependent Variable: Whole tree

\begin{tabular}{ccccccccccc}
\hline \multirow{2}{*}{ Equation } & \multicolumn{1}{c}{ Model Summary } & \multicolumn{8}{c}{ Parameter Estimates } \\
& R Square & F & df1 & df2 & p-value & Constant & b1 & b2 & b3 \\
\hline Linear & 0.920 & 115.406 & 1 & 10 & 0.000 & 80.127 & 2.333 \\
Quadratic & 0.997 & 1560.326 & 2 & 9 & 0.000 & 165.225 & -12.231 & 0.552 & \\
Cubic & 0.997 & 1540.912 & 2 & 9 & 0.000 & 143.639 & -6.115 & 0.000 & 0.016 \\
& \multicolumn{1}{c}{ The independent variable is Small branch. }
\end{tabular}

Figure S2. Regression of total carbon in whole tree and small branch of RRIM 2020 planted at 1000 plants/ha density. 


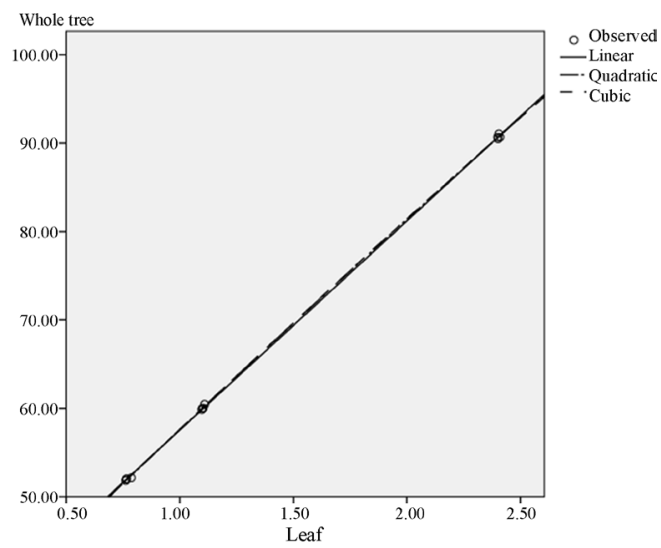

Model Summary and Parameter Estimates

Dependent Variable: Whole tree

\begin{tabular}{cccccccccc}
\hline \multirow{3}{*}{ Equation } & \multicolumn{1}{c}{ Model Summary } & \multicolumn{8}{c}{ Parameter Estimates } \\
& R Square & F & df1 & df2 & p-value & Constant & b1 & b2 & b3 \\
\hline Linear & 1.000 & 75698.681 & 1 & 10 & 0.000 & 33.903 & 23.645 & & \\
Quadratic & 1.000 & 44550.952 & 2 & 9 & 0.000 & 32.881 & 25.215 & -0.481 & \\
Cubic & 1.000 & 44729.815 & 2 & 9 & 0.000 & 33.105 & 24.620 & 0.000 & -0.113 \\
& \multicolumn{9}{c}{ The independent variable is Leaf. } \\
\hline
\end{tabular}

Figure S3. Regression of total carbon in whole tree and leaf of RRIM 2020 planted at 1500 plants/ha density.

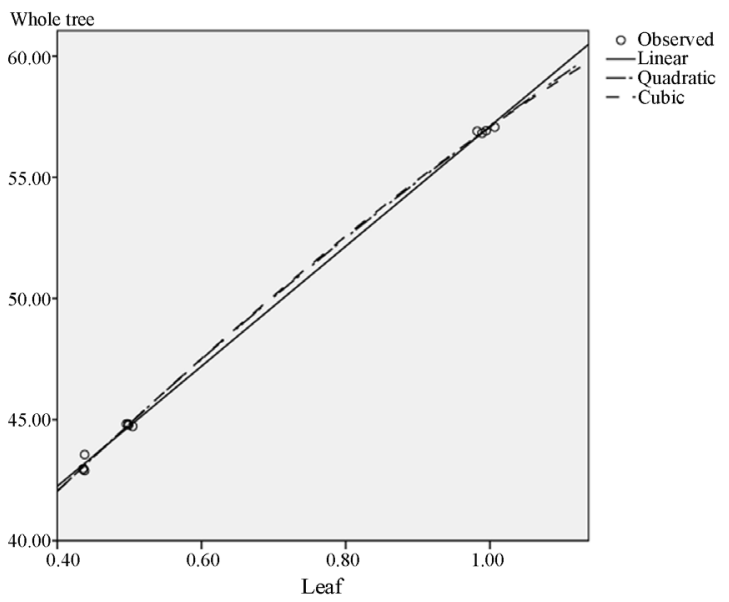

Model Summary and Parameter Estimates

Dependent Variable: Whole tree

\begin{tabular}{ccccccccccc}
\hline \multicolumn{10}{c}{ Model Summary } & \multicolumn{7}{c}{ Parameter Estimates } \\
Equation & R Square & F & df1 & df2 & p-value & Constant & b1 & b2 & b3 \\
\hline Linear & 0.999 & 9957.097 & 1 & 10 & 0.000 & 32.350 & 24.756 \\
Quadratic & 0.999 & 5223.117 & 2 & 9 & 0.000 & 29.858 & 32.639 & -5.421 & \\
Cubic & 0.999 & 5306.813 & 2 & 9 & 0.000 & 30.403 & 29.570 & 0.000 & -2.903 \\
& \multicolumn{10}{c}{ The independent variable is Leaf. } \\
\hline
\end{tabular}

Figure S4. Regression of total carbon in whole tree and leaf of RRIM 2020 planted at 2000 plants/ha density. 


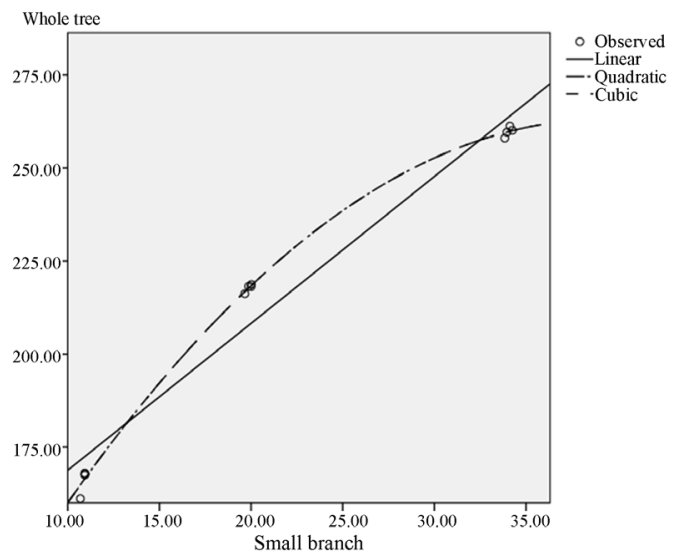

\begin{tabular}{|c|c|c|c|c|c|c|c|c|c|}
\hline \multicolumn{10}{|c|}{ Model Summary and Parameter Estimates } \\
\hline \multicolumn{10}{|c|}{ Dependent Variable: Whole tree } \\
\hline \multirow{2}{*}{ Equation } & \multicolumn{5}{|c|}{ Model Summary } & \multicolumn{4}{|c|}{ Parameter Estimates } \\
\hline & R Square & $\mathrm{F}$ & df1 & $\mathrm{df} 2$ & $\mathrm{p}$-value & Constant & b1 & b2 & b3 \\
\hline Linear & 0.964 & 266.063 & 1 & 10 & 0.000 & 129.345 & 3.946 & & \\
\hline Quadratic & 0.999 & 3430.679 & 2 & 9 & 0.000 & 77.794 & 9.427 & -0.120 & \\
\hline Cubic & 0.999 & 3430.679 & 2 & 9 & 0.000 & 77.794 & 9.427 & -0.120 & 0.000 \\
\hline \multicolumn{10}{|c|}{ The independent variable is Small branch. } \\
\hline
\end{tabular}

Figure S5. Regression of total carbon in whole tree and small branch of RRIM 2025 planted at 500 plants/ha density.

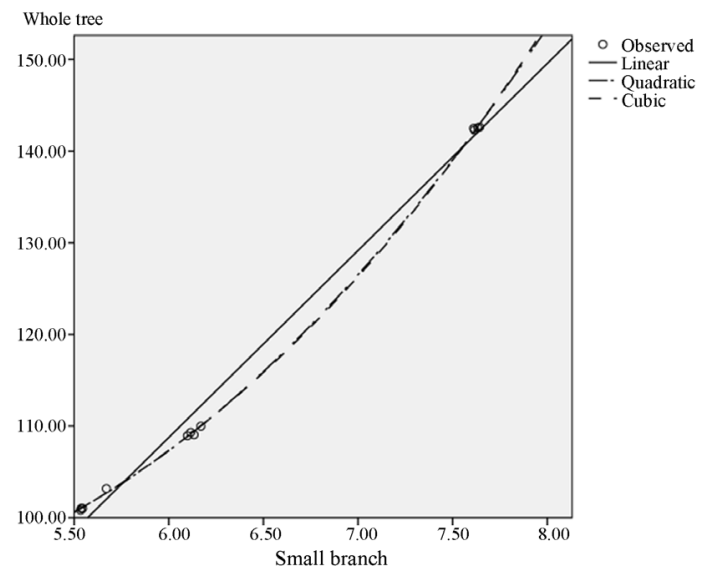

Model Summary and Parameter Estimates

Dependent Variable: Whole tree

\begin{tabular}{cccccccccc}
\hline \multirow{2}{*}{ Equation } & \multicolumn{9}{c}{ Model Summary } \\
& R Square & F & df1 & df2 & p-value & Constant & b1 & b2 & b3 \\
\hline Linear & 0.993 & 1346.256 & 1 & 10 & 0.000 & -13.676 & 20.404 \\
Quadratic & 1.000 & 21772.241 & 2 & 9 & 0.000 & 154.983 & -31.218 & 3.879 & \\
Cubic & 1.000 & 22046.227 & 2 & 9 & 0.000 & 89.179 & 0.000 & -1.017 & 0.254 \\
& \multicolumn{8}{c}{ The independent variable is Small branch. } \\
\hline
\end{tabular}

Figure S6. Regression of total carbon in whole tree and small branch of RRIM 2025 planted at 1000 plants/ha density. 


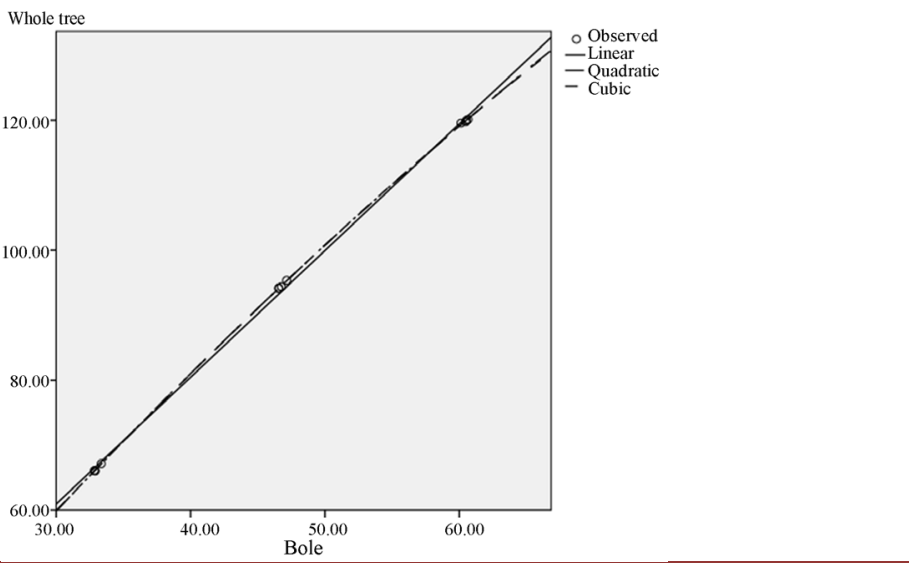

Model Summary and Parameter Estimates

Dependent Variable: Whole tree

\begin{tabular}{|c|c|c|c|c|c|c|c|c|c|}
\hline \multirow{2}{*}{ Equation } & \multicolumn{5}{|c|}{ Model Summary } & \multicolumn{4}{|c|}{ Parameter Estimates } \\
\hline & R Square & $\mathrm{F}$ & df1 & df2 & $\mathrm{p}$-value & Constant & b1 & b2 & b3 \\
\hline Linear & 0.999 & 11607.089 & 1 & 10 & 0.000 & 2.458 & 1.950 & & \\
\hline Quadratic & 1.000 & 188610.826 & 2 & 9 & 0.000 & -12.169 & 2.614 & -0.007 & \\
\hline Cubic & 1.000 & 193720.263 & 2 & 9 & 0.000 & -7.442 & 2.292 & 0.000 & $-5.076 \mathrm{E}-005$ \\
\hline \multicolumn{10}{|c|}{ The independent variable is Bole. } \\
\hline
\end{tabular}

Figure S7. Regression of total carbon in whole tree and bole of RRIM 2025 planted at 1500 plants/ha density.

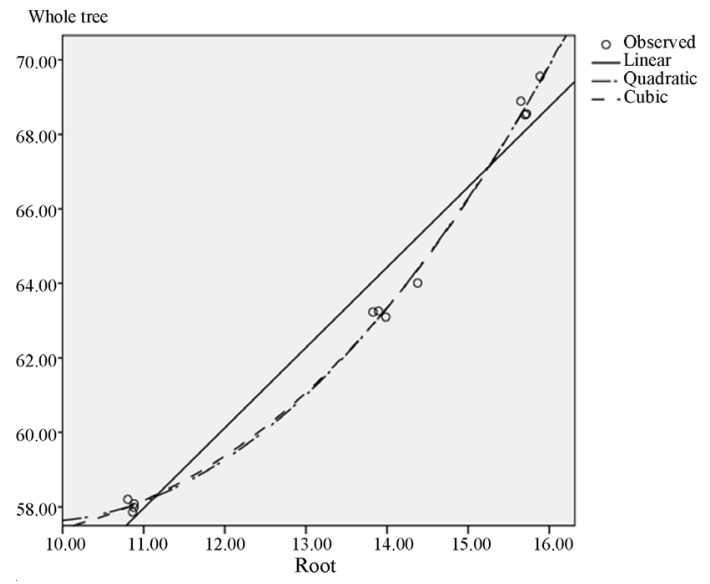

\begin{tabular}{ccccccccccc}
\hline \multicolumn{1}{c}{ Model Summary and Parameter Estimates } \\
Dependent Variable: Whole tree \\
Equation & Model Summary & \multicolumn{7}{c}{ Parameter Estimates } \\
& R Square & F & df1 & df2 & p-value & Constant & b1 & b2 & b3 \\
\hline Linear & 0.967 & 294.540 & 1 & 10 & 0.000 & 34.252 & 2.156 & & \\
Quadratic & 0.997 & 1642.151 & 2 & 9 & 0.000 & 85.960 & -5.875 & 0.304 & \\
Cubic & 0.997 & 1693.289 & 2 & 9 & 0.000 & 60.114 & 0.000 & -0.135 & 0.011 \\
& \multicolumn{8}{c}{ The independent variable is Root. } \\
\hline
\end{tabular}

Figure S8. Regression of total carbon in whole tree and root of RRIM 2025 planted at 2000 plants/ha density. 
Table S6. Trend analysis for total carbon in plant parts of RRIM 2020 in different densities using orthogonal polynomials calculation.

\begin{tabular}{|c|c|c|c|c|c|}
\hline Plant parts & SOV & $\mathrm{df}$ & MS & VR & \\
\hline \multirow{4}{*}{ Leaf } & Linear & 1 & 0.06792819 & 0.25 & ns \\
\hline & Quadratic & 1 & 0.20225382 & 0.75 & ns \\
\hline & Cubic & 1 & 11.56829321 & 43.17 & $* * * *$ \\
\hline & Error & 44 & 0.26795451 & & \\
\hline \multirow{4}{*}{ Petiole } & Linear & 1 & 0.04856005 & 5.86 & * \\
\hline & Quadratic & 1 & 0.03279870 & 3.96 & ns \\
\hline & Cubic & 1 & 0.27336418 & 33.00 & $* * * * x$ \\
\hline & Error & 44 & 0.00828323 & & \\
\hline \multirow{4}{*}{ Twig } & Linear & 1 & 36.05492021 & 69.78 & $* * * *$ \\
\hline & Quadratic & 1 & 7.64302619 & 14.79 & $* * *$ \\
\hline & Cubic & 1 & 3.88539181 & 7.52 & $* *$ \\
\hline & Error & 44 & 0.51666291 & & \\
\hline \multirow{4}{*}{ Small branch } & Linear & 1 & 1530.592559 & 61.62 & $* * * *$ \\
\hline & Quadratic & 1 & 9.870979 & 0.40 & ns \\
\hline & Cubic & 1 & 40.236632 & 1.62 & ns \\
\hline & Error & 44 & 24.837586 & & \\
\hline \multirow{4}{*}{ Large branch } & Linear & 1 & 48338.23342 & 120.29 & $* * * *$ \\
\hline & Quadratic & 1 & 11884.23656 & 29.57 & $* * * * x$ \\
\hline & Cubic & 1 & 2287.45436 & 5.69 & * \\
\hline & Error & 44 & 401.84414 & & \\
\hline \multirow{4}{*}{ Bole } & Linear & 1 & 3400.705430 & 46.60 & $* * * * x$ \\
\hline & Quadratic & 1 & 138.375631 & 1.90 & ns \\
\hline & Cubic & 1 & 177.525188 & 2.43 & ns \\
\hline & Error & 44 & 72.980153 & & \\
\hline \multirow{4}{*}{ Bark } & Linear & 1 & 75.20658041 & 71.76 & $* * * *$ \\
\hline & Quadratic & 1 & 6.21084344 & 5.93 & * \\
\hline & Cubic & 1 & 11.19839205 & 10.69 & $* *$ \\
\hline & Error & 44 & 1.0480471 & & \\
\hline \multirow{4}{*}{ Root } & Linear & 1 & 1964.953470 & 100.48 & $* * * *$ \\
\hline & Quadratic & 1 & 12.557578 & 0.64 & ns \\
\hline & Cubic & 1 & 22.092952 & 1.13 & ns \\
\hline & Error & 44 & 37.26 & & \\
\hline \multirow{4}{*}{ Whole } & Linear & 1 & 141965.7831 & 191.99 & $* * * *$ \\
\hline & Quadratic & 1 & 14708.7373 & 19.89 & $* * * * x$ \\
\hline & Cubic & 1 & 486.9284 & 0.66 & ns \\
\hline & Error & 44 & 739.4398 & & \\
\hline
\end{tabular}

SOV: Source of variation; df: Degree of freedom; MS: Mean square; VR: Variance ratio; ns: Non-significant; ${ }^{* * * *},{ }^{* * *},{ }^{* *},{ }^{*}$ : significant at $\mathrm{p}<0.0001, \mathrm{p}<0.001, \mathrm{p}<0.01, \mathrm{p}<0.05$ respectively. 


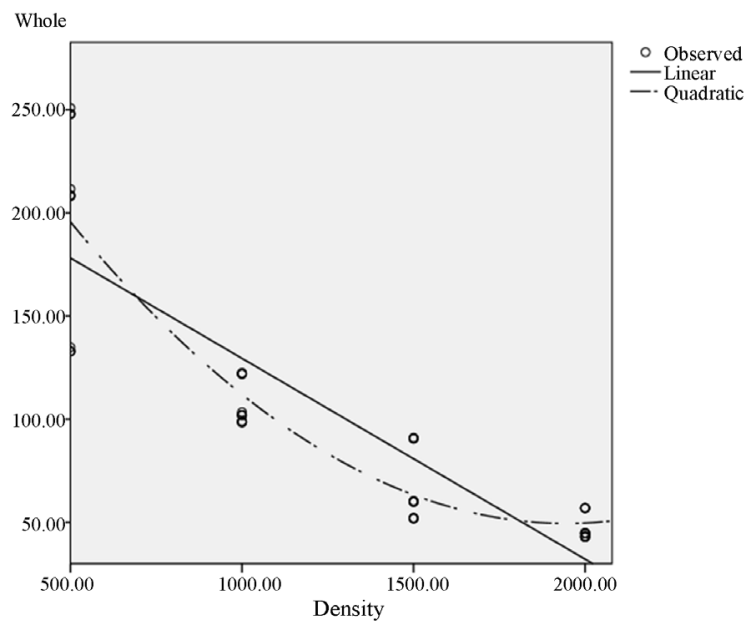

Model Summary and Parameter Estimates

Dependent Variable: Whole tree

\begin{tabular}{|c|c|c|c|c|c|c|c|c|}
\hline \multirow{2}{*}{ Equation } & \multicolumn{5}{|c|}{ Model Summary } & \multicolumn{3}{|c|}{ Parameter Estimates } \\
\hline & R Square & $\mathrm{F}$ & df1 & $\mathrm{df} 2$ & p-value & Constant & b1 & b2 \\
\hline Linear & 0.748 & 136.817 & 1 & 46 & 0.000 & 226.760 & -0.097 & \\
\hline Quadratic & 0.826 & 106.751 & 2 & 45 & 0.000 & 314.286 & -0.272 & $7.002 \mathrm{E}-005$ \\
\hline \multicolumn{9}{|c|}{ The independent variable is Density. } \\
\hline
\end{tabular}

Figure S9. Regression analysis of total carbon per tree in RRIM 2020 in different densities.

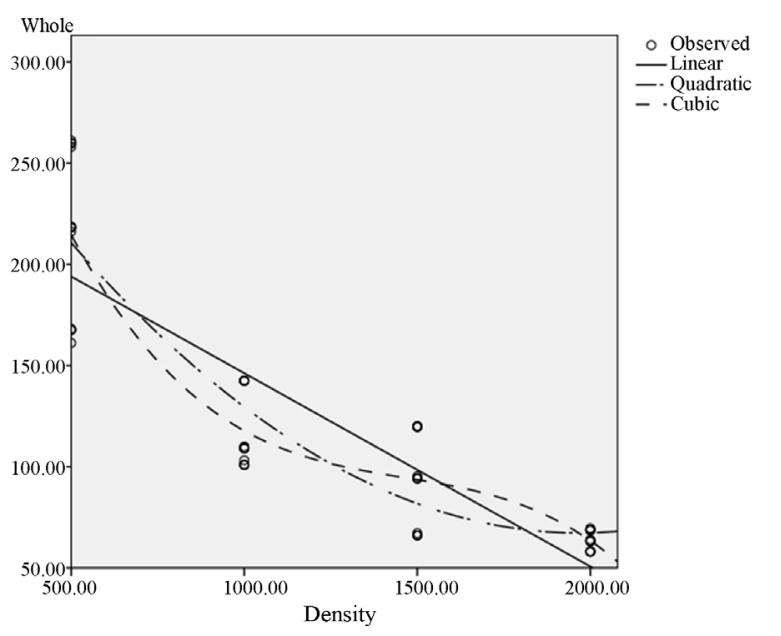

Model Summary and Parameter Estimates

Dependent Variable: Whole Tree

\begin{tabular}{ccccccccccc}
\hline \multicolumn{1}{c}{ Equation } & \multicolumn{1}{c}{ Model Summary } & \multicolumn{7}{c}{ Parameter Estimates } \\
& R Square & F & df1 & df2 & p-value & Constant & b1 & b2 & b3 \\
\hline Linear & 0.755 & 141.681 & 1 & 46 & 0.000 & 241.732 & -0.096 & & \\
Quadratic & 0.828 & 108.646 & 2 & 45 & 0.000 & 325.056 & -0.262 & $6.666 \mathrm{E}-005$ & \\
Cubic & 0.849 & 82.361 & 3 & 44 & 0.000 & 462.459 & -0.699 & 0.000 & $-1.047 \mathrm{E}-007$ \\
& & \multicolumn{8}{c}{ The independent variable is Density. } \\
\hline
\end{tabular}

Figure S10. Regression analysis of total carbon per tree in RRIM 2025 in different densities. 
Table S7. Trend analysis for total carbon in plant parts of RRIM 2025 in different densities using orthogonal polynomials calculation.

\begin{tabular}{|c|c|c|c|c|c|}
\hline Plant parts & SOV & $\mathrm{df}$ & MS & VR & \\
\hline \multirow{4}{*}{ Leaf } & Linear & 1 & 6.46997555 & 10.24 & $* *$ \\
\hline & Quadratic & 1 & 2.03568406 & 3.22 & ns \\
\hline & Cubic & 1 & 5.26547524 & 8.34 & $* *$ \\
\hline & Error & 44 & 0.63154782 & & \\
\hline \multirow{4}{*}{ Petiole } & Linear & 1 & 0.35666325 & 2.38 & ns \\
\hline & Quadratic & 1 & 1.07083275 & 7.14 & * \\
\hline & Cubic & 1 & 0.64733908 & 4.32 & * \\
\hline & Error & 44 & 0.14991591 & & \\
\hline \multirow{4}{*}{ Twig } & Linear & 1 & 86.35002942 & 97.57 & $* * * *$ \\
\hline & Quadratic & 1 & 8.55091996 & 9.66 & $* *$ \\
\hline & Cubic & 1 & 17.62328068 & 19.91 & $* * * *$ \\
\hline & Error & 44 & 0.8850322 & & \\
\hline \multirow{4}{*}{ Small branch } & Linear & 1 & 1945.317758 & 73.81 & $* * * *$ \\
\hline & Quadratic & 1 & 613.330530 & 23.27 & $* * * *$ \\
\hline & Cubic & 1 & 80.297793 & 3.05 & ns \\
\hline & Error & 44 & 26.354068 & & \\
\hline \multirow{4}{*}{ Large branch } & Linear & 1 & 37159.31722 & 127.84 & $* * * *$ \\
\hline & Quadratic & 1 & 2425.23551 & 8.34 & $* *$ \\
\hline & Cubic & 1 & 2.42951 & 0.01 & ns \\
\hline & Error & 44 & 290.66298 & & \\
\hline \multirow{4}{*}{ Bole } & Linear & 1 & 2362.560289 & 9.29 & $* *$ \\
\hline & Quadratic & 1 & 66.603599 & 0.26 & ns \\
\hline & Cubic & 1 & 601.957945 & 2.37 & ns \\
\hline & Error & 44 & 254.26554 & & \\
\hline \multirow{4}{*}{ Bark } & Linear & 1 & 23.80914706 & 6.33 & * \\
\hline & Quadratic & 1 & 6.14977415 & 1.63 & ns \\
\hline & Cubic & 1 & 12.80103499 & 3.40 & ns \\
\hline & Error & 44 & 3.7639678 & & \\
\hline \multirow{4}{*}{ Root } & Linear & 1 & 4507.975616 & 163.02 & $* * * *$ \\
\hline & Quadratic & 1 & 755.575531 & 27.32 & $* * * *$ \\
\hline & Cubic & 1 & 272.173618 & 9.84 & $* *$ \\
\hline & Error & 44 & 27.653724 & 3698.8363 & \\
\hline \multirow{4}{*}{ Whole } & Linear & 1 & 136850.9230 & 219.74 & $* * * *$ \\
\hline & Quadratic & 1 & 13330.3329 & 21.40 & $* * * *$ \\
\hline & Cubic & 1 & 3698.8363 & 5.94 & * \\
\hline & Error & 44 & 622.7900 & & \\
\hline
\end{tabular}

SOV: Source of variation; df: Degree of freedom; MS: Mean square; VR: Variance ratio; ns: Non-significant; ${ }^{* * * *},{ }^{* * *},{ }^{* *},{ }^{*}$ : significant at $\mathrm{p}<0.0001, \mathrm{p}<0.001, \mathrm{p}<0.01, \mathrm{p}<0.05$ respectively. 
Table S8. Total content of carbon per hectare for RRIM 2020 and RRIM 2025 in the different planting density.

\begin{tabular}{|c|c|c|c|c|c|c|}
\hline \multirow{2}{*}{$\begin{array}{l}\text { Planting density } \\
\text { (plants/ha) }\end{array}$} & \multirow{2}{*}{ Clone } & \multicolumn{5}{|c|}{ Plant parts } \\
\hline & & Leaf $(\mathrm{kg})$ & Petiole (kg) & Twig (kg) & Small & pranch (kg) \\
\hline \multirow[t]{2}{*}{500} & $\begin{array}{l}\text { RRIM } \\
2020\end{array}$ & $592 \pm 97$ & $130 \pm 18$ & $2032 \pm 165$ & \multicolumn{2}{|c|}{$8070 \pm 1199$} \\
\hline & $\begin{array}{l}\text { RRIM } \\
2025\end{array}$ & $1162 \pm 203$ & $131 \pm 19$ & $2650 \pm 200$ & \multicolumn{2}{|c|}{$1080 \pm 1438$} \\
\hline \multirow[t]{2}{*}{1000} & $\begin{array}{l}\text { RRIM } \\
2020\end{array}$ & $142 \pm 30$ & $45 \pm 4$ & $3000 \pm 29$ & \multicolumn{2}{|c|}{$11819 \pm 1276$} \\
\hline & $\begin{array}{l}\text { RRIM } \\
2025\end{array}$ & $992 \pm 69$ & $692 \pm 218$ & $2173 \pm 69$ & \multicolumn{2}{|c|}{$6442 \pm 262$} \\
\hline \multirow[t]{2}{*}{1500} & $\begin{array}{c}\text { RRIM } \\
2020\end{array}$ & $2138 \pm 319$ & $329 \pm 54$ & $2192 \pm 177$ & \multicolumn{2}{|c|}{$6468 \pm 1377$} \\
\hline & $\begin{array}{c}\text { RRIM } \\
2025\end{array}$ & $2328 \pm 286$ & $455 \pm 42$ & $3899 \pm 499$ & \multicolumn{2}{|c|}{$6328 \pm 909$} \\
\hline \multirow[t]{2}{*}{2000} & $\begin{array}{c}\text { RRIM } \\
2020\end{array}$ & $1286 \pm 150$ & $216 \pm 25$ & $3987 \pm 438$ & \multicolumn{2}{|c|}{$3612 \pm 472$} \\
\hline & $\begin{array}{c}\text { RRIM } \\
2025\end{array}$ & $2087 \pm 127$ & $271 \pm 22$ & $2320 \pm 278$ & \multicolumn{2}{|c|}{$6720 \pm 556$} \\
\hline \multirow{2}{*}{$\begin{array}{l}\text { Planting density } \\
\text { (plants/ha) }\end{array}$} & \multicolumn{6}{|c|}{ Plant parts } \\
\hline & Clone & $\begin{array}{l}\text { Large branch } \\
(\mathrm{kg})\end{array}$ & Bole (kg) & Bark (kg) & Root $(\mathrm{kg})$ & Whole tree $(\mathrm{kg})$ \\
\hline \multirow[t]{2}{*}{500} & $\begin{array}{l}\text { RRIM } \\
2020\end{array}$ & $46522 \pm 5608$ & $26099 \pm 1497$ & $2789 \pm 209$ & $12291 \pm 1097$ & $98524 \pm 7213$ \\
\hline & $\begin{array}{l}\text { RRIM } \\
2025\end{array}$ & $39606 \pm 4217$ & $29235 \pm 3845$ & $2861 \pm 490$ & $20836 \pm 1271$ & $107282 \pm 5779$ \\
\hline \multirow[t]{2}{*}{1000} & $\begin{array}{l}\text { RRIM } \\
2020\end{array}$ & $20841 \pm 2782$ & $44713 \pm 2045$ & $6042 \pm 337$ & $21095 \pm 1047$ & $107697 \pm 3102$ \\
\hline & $\begin{array}{c}\text { RRIM } \\
2025\end{array}$ & $39708 \pm 4766$ & $43504 \pm 3370$ & $3453 \pm 333$ & $20810 \pm 814$ & $117774 \pm 5361$ \\
\hline \multirow[t]{2}{*}{1500} & $\begin{array}{l}\text { RRIM } \\
2020\end{array}$ & $16471 \pm 902$ & $48036 \pm 4909$ & $5439 \pm 309$ & $20328 \pm 886$ & $101401 \pm 7544$ \\
\hline & $\begin{array}{c}\text { RRIM } \\
2025\end{array}$ & $23138 \pm 2254$ & $70096 \pm 5069$ & $6313 \pm 587$ & $27798 \pm 1967$ & $140355 \pm 9888$ \\
\hline \multirow[t]{2}{*}{2000} & $\begin{array}{l}\text { RRIM } \\
2020\end{array}$ & $3435 \pm 513$ & $62663 \pm 1366$ & $5302 \pm 280$ & $16040 \pm 1015$ & $96542 \pm 3718$ \\
\hline & $\begin{array}{l}\text { RRIM } \\
2025\end{array}$ & $8706 \pm 1762$ & $72954 \pm 3379$ & $6741 \pm 358$ & $27078 \pm 1222$ & $126877 \pm 2678$ \\
\hline
\end{tabular}

Note: Values calculated by multiplying number of trees per hectare with total content of carbon per tree.

Table S9. ANOVA and Duncan's grouping for total content of carbon per hectare in the different planting density.

\begin{tabular}{ccccccccc}
\hline \multirow{2}{*}{ Clone } & $\begin{array}{c}\text { Plant } \\
\text { parts }\end{array}$ & df & MS & VR & 500 t/ha & 1000 t/ha & 1500 t/ha & 2000 t/ha \\
& Leaf & 3 & 9095976 & $23^{*}$ & C & C & A & B \\
\multirow{2}{*}{$\begin{array}{c}\text { RRIM } \\
2020\end{array}$} & Petiole & 3 & 176247 & $15^{*}$ & B & C & A & B \\
& Twig & 3 & 9629244 & $13^{*}$ & C & B & C & A \\
& $\begin{array}{c}\text { Small } \\
\text { branch }\end{array}$ & 3 & $\begin{array}{c}14066139 \\
8\end{array}$ & $9^{*}$ & B & A & BC & C \\
\hline
\end{tabular}




\section{Continued}

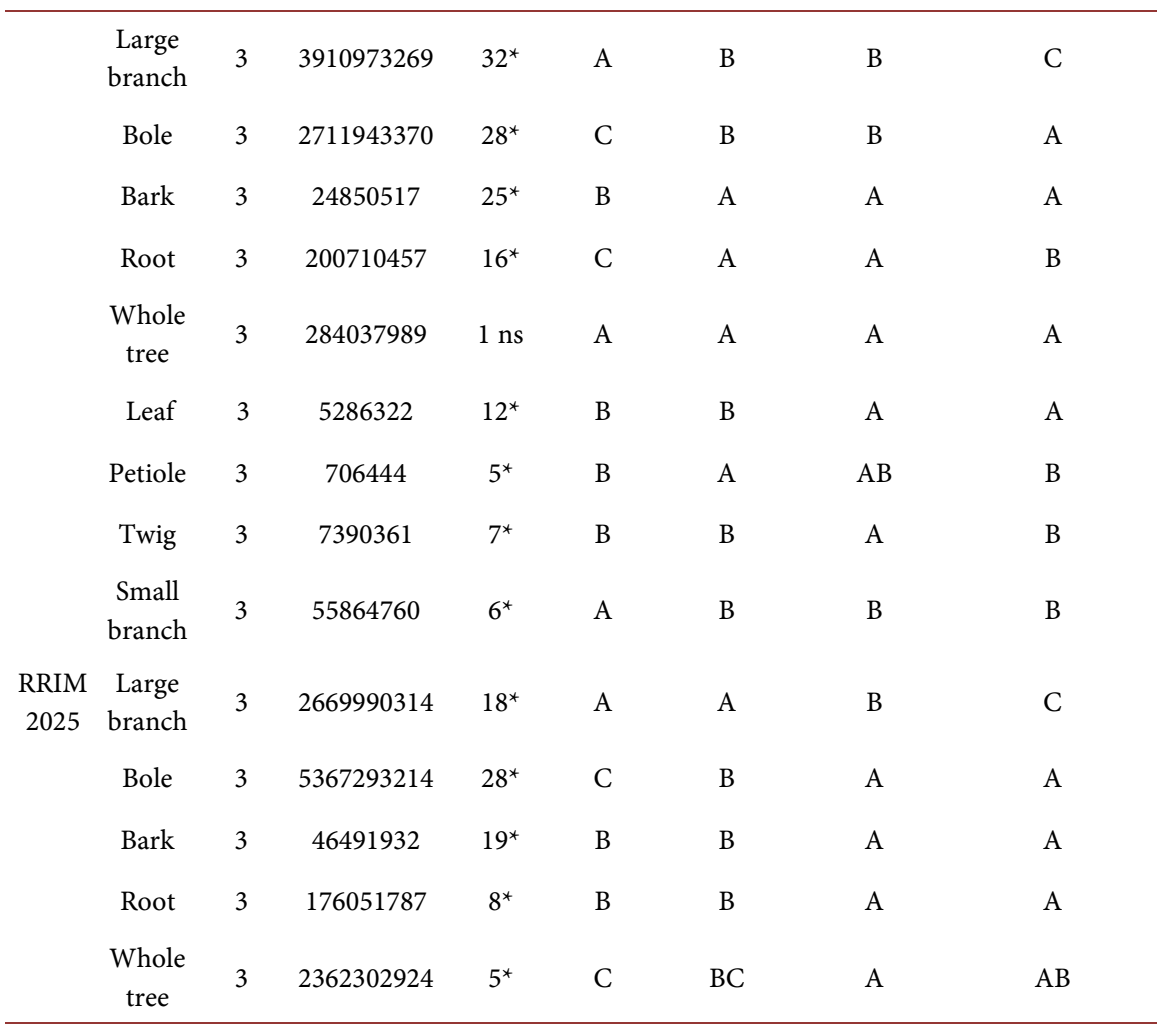

Note: ANOVA, df: Degree of freedom; MS: Mean square; VR: Variance ratio; ns: Non-significant; ${ }^{*}$ : significant at $\mathrm{p}<0.05$. Planting density with the same alphabet are in the same homogenous subset for mean total content of carbon per hectare.

Table S10. Mean comparison of total content of carbon per hectare between clones (RRIM 2020 - RRIM 2025) using Student's t-test.

\begin{tabular}{cccccc}
\hline $\begin{array}{c}\text { Density } \\
\text { (plants/hectare) }\end{array}$ & Plant parts & Mean difference $(\mathrm{kg})$ & $\mathrm{t}$ & $\mathrm{df}$ & \\
& Leaf & -570.775 & -2.534 & 15.749 & * \\
& Petiole & -0.943 & -0.036 & 22 & $\mathrm{~ns}$ \\
& Twig & -618.203 & -2.381 & 22 & $*$ \\
& Small branch & -2730.03 & -1.458 & 22 & $\mathrm{~ns}$ \\
& Large branch & 6915.274 & 0.986 & 22 & $\mathrm{~ns}$ \\
& Bole & -3136.212 & -0.76 & 14.261 & $\mathrm{~ns}$ \\
& Bark & -72.161 & -0.136 & 14.865 & $\mathrm{~ns}$ \\
& Root & -8545.689 & -5.089 & 22 & $*$ \\
& Whole tree & -8758.739 & -0.948 & 22 & $\mathrm{~ns}$ \\
& Leaf & -850.48 & -11.317 & 15.006 & $*$ \\
& Petiole & -646.978 & -2.967 & 11.008 & $*$ \\
& Twig & 826.998 & 11.076 & 14.879 & $*$ \\
& Small branch & 5376.975 & 4.129 & 11.925 & $*$ \\
& Large branch & -18867.119 & -3.419 & 17.715 & $*$ \\
\hline
\end{tabular}




\section{Continued}

\begin{tabular}{|c|c|c|c|c|c|}
\hline & Bole & 1209.3 & 0.307 & 18.134 & $\mathrm{~ns}$ \\
\hline & Bark & 2589.177 & 5.468 & 22 & * \\
\hline & Root & 285.147 & 0.215 & 22 & $\mathrm{~ns}$ \\
\hline & Whole tree & -10076.979 & -1.627 & 17.624 & $\mathrm{~ns}$ \\
\hline & Leaf & -190.771 & -0.446 & 22 & $\mathrm{~ns}$ \\
\hline & Petiole & -126.331 & -1.833 & 22 & $\mathrm{~ns}$ \\
\hline & Twig & -1706.756 & -3.223 & 13.723 & * \\
\hline & Small branch & 139.51 & 0.085 & 19.053 & $\mathrm{~ns}$ \\
\hline \multirow[t]{9}{*}{1500} & Large branch & -6667.375 & -2.746 & 14.434 & * \\
\hline & Bole & -22060.175 & -3.126 & 22 & * \\
\hline & Bark & -873.318 & -1.317 & 16.652 & $\mathrm{~ns}$ \\
\hline & Root & -7469.357 & -3.463 & 15.282 & * \\
\hline & Whole tree & -38954.573 & -3.132 & 22 & * \\
\hline & Leaf & -800.42 & -4.064 & 22 & * \\
\hline & Petiole & -54.605 & -1.628 & 22 & $\mathrm{~ns}$ \\
\hline & Twig & 1666.85 & 3.213 & 18.627 & * \\
\hline & Small branch & -3108.816 & -4.263 & 22 & * \\
\hline \multirow[t]{5}{*}{2000} & Large branch & -5270.834 & -2.873 & 12.851 & * \\
\hline & Bole & -10290.639 & -2.824 & 14.504 & * \\
\hline & Bark & -1438.632 & -3.163 & 22 & * \\
\hline & Root & -11038.068 & -6.949 & 22 & * \\
\hline & Whole tree & -30335.163 & -6.621 & 19.996 & * \\
\hline
\end{tabular}

Note: t: t-value; df: Degree of freedom; ns: Non-significant; ${ }^{*}$ : significant at $\mathrm{p}<0.05$. 